\title{
Chronology of recent sedimentary infill of the Inner Río de la Plata Estuary, Argentina
}

\author{
Ferran Colombo $^{1}$ D $\cdot$ Jordi Serra ${ }^{1} \cdot$ Patricia Cabello ${ }^{1} \cdot$ José Bedmar $^{2} \cdot$ Federico I. Isla $^{3}$
}

Received: 29 March 2021 / Accepted: 2 August 2021 / Published online: 24 August 2021

(c) The Author(s) 2021

\begin{abstract}
The Inner Río de la Plata Estuary is a sedimentary depositional system that resulted from fluvial-deltaic activity. Gentle Pliocene-Pleistocene slopes make-up the northern side of the estuary whereas small cliffs of the same age constitute the southern side. A long coastal estuarine barrier developed at about 6000 years BP when the maximum flooding surface occurred. Attached to this barrier, and at a lower elevation, is a large strandplain (covering an area of about $2400 \mathrm{~km}^{2}$ ) which displays more than 220 beach ridges. In different areas, the dating indicates a periodicity of 13.4-13.7 years for the development of each beach ridge. These data are like the periodicity of the ENSO effects, which could be associated with the variability of Sunspots. These ridges were formed shortly after the maximum flooding surface, which was followed by a gradual fall in sea-level that contributed significantly to the Inner Río de la Plata Estuary sedimentary infill. In addition, ENSO activities were probably instrumental in the distribution of the main geoforms in the Inner Rio de la Plata Estuary. Small deltas, which were generated by other rivers and creeks such as the Nogoyá Arroyo and the Gualeguay River, developed coevally with the coastal estuarine barrier. The Ibicuy Delta grew in the middle of the inner Río de la Plata Estuary when the former Paraná River flowed northwards during the sea-level fall. The upper part of the delta front was reworked, giving rise to a large dunefield. Thereafter, a chenier plain developed along with tidal flats. The current Paraná Delta continues to prograde at a rate of about 56-64 m/year $\left(\mathrm{m} \mathrm{year}^{-1}\right)$. The sedimentary infill of the Inner Río de la Plata Estuary occurred along the Holocene.
\end{abstract}

Keywords Holocene dating $\cdot$ OSL data $\cdot{ }^{14} \mathrm{C}$ data $\cdot$ Inner Río de la Plata Estuary sedimentary infill $\cdot$ Province of Entre Ríos · Argentina

Ferran Colombo

colombo@ub.edu

Jordi Serra

jordi.serra@ub.edu

Patricia Cabello

pcabello@ub.edu

José Bedmar

josebedmar@gmail.com

Federico I. Isla

fisla9@gmail.com

1 Department de Dinàmica de La Terra i de l'Oceà, Facultat de Ciències de la Terra, Universitat de Barcelona, C/ Martí-i-Franquès s/n, 08028 Barcelona, Spain

2 Servicio Geológico Minero Argentino (SEGEMAR), Avda. General Paz 5445, Parque Tecnológico Miguelete Edif, 14/25, San Martin, B1650WAB Buenos Aires, Argentina

3 Instituto de Geología de Costas y del Cuaternario, Universidad Nacional de Mar del Plata, CONICET, Dean Funes 3350, 7600 Mar del Plata, Argentina 


\section{Cronología del relleno sedimentario reciente de la parte más interna del estuario del Río de la Plata, Argentina}

\section{Resumen}

La parte más interna del Estuario del Río de la Plata corresponde a un Sistema Deposicional generado por la interacción de la actividad sedimentaria fluvial y deltaica. El margen septentrional del estuario está formado por suaves lomadas de materiales Pliocenos y Pleistocenos, mientras que el margen austral del estuario está formado por pequeños cantiles que afectan a materiales de la misma edad. A lo largo de 6000 yrBP se desarrolló una gran barrera costera-estuárica cuando se alcanzó la máxima superficie de inundación. Adyacente a esta barrera, y a una elevación un poco menor, existe una gran llanura costera (que abarca una superficie del orden de $2400 \mathrm{~km}^{2}$ ) que muestra más de 220 cordones de playa. Las dataciones realizas en diferentes zonas indican una periodicidad de 13.4-13.7 años para el desarrollo de cada cordón de playa. Estos datos son del mismo orden de magnitud que la periodicidad de los efectos del ENSO, y podrían estar relacionados con la variabilidad de las manchas solares. Estos cordones se generaron inmediatamente después de alcanzar la máxima superficie de inundación, que fue seguida por una caída gradual del nivel del mar y contribuyó al relleno sedimentario. Además, las actividades del ENSO contribuyeron probablemente a la distribución de las principales geoformas en la parte interior del Estuario del Río de la Plata. También se generaron pequeños deltas por la actividad de otros ríos y torrentes como el Arroyo Nogoyá y el Río Gualeguay desarrollados sincrónicamente a la barrera costera estuárica. El Delta de Ibicuy evolucionó en el medio de la parte interna del Estuario del Río de la Plata cuando el antiguo Río Paraná fluía hacia el nordeste durante la caída del nivel del mar. La parte alta del frente deltaico fue retrabajada dando lugar a un gran campo de dunas eólicas. Posteriormente una llanura de cheniers se desarrolló junto a las llanuras deltaicas. El actual Delta del Paraná continúa su progradación con una tasa de unos 56-64 m/y. El relleno sedimentario de la parte interna del Estuario del Río de la Plata se desarrolló a lo largo del Holoceno.

Palabras clave Datación del Holoceno $\cdot$ datos de OSL $\cdot$ datos de ${ }^{14} \mathrm{C} \cdot$ Relleno sedimentario de la parte más interna del Estuario del Río de la Plata · Provincia de Entre Ríos · Argentina

\section{Introduction}

The inner part of the Río de la Plata Estuary (IRPE) is located close to the confluence of the Paraná and Uruguay rivers (Fig. 1). The sedimentary accumulation resulted mainly from the Paraná River and to a lesser extent from the Uruguay River. The upstream part of the IRPE is a freshwater environment because of large discharges of the Paraná and Uruguay Rivers (Urien, 1972). The Paraná River, which is one of the biggest rivers in South America, has a drainage area of about $3 \times 10^{6} \mathrm{Km}^{2}$ that extends from Bolivia, Paraguay, Brazil, and northern Argentina to the estuary. Although its current discharge is about $16,000 \mathrm{~m}^{3} /$ second $\left(\mathrm{m}^{3} \mathrm{~s}^{-1}\right)$, it attains approximately $65,000 \mathrm{~m}^{3} \mathrm{~s}^{-1}$ in times of extensive flooding (Antico et al., 2016; Camilloni \& Barros, 2003; García \& Mechoso, 2005; Orfeo, 1995). The suspended load is mainly composed of clays and silts yielding about $200 \times 10^{6}$ tons/year ( $\mathrm{t}_{\text {year }}{ }^{-1}$ ) whereas the bed load is constituted by very fine-to-fine siliceous sands, attaining values between 5 and $15 \times 10^{6} \mathrm{t} \mathrm{year}^{-1}$. Note that the load is not proportional to the increase in the discharge since the low rainfall in the sparsely vegetated area of eastern Bolivia results in a considerable increase in bed load. By contrast, heavy rainfall in Amazonia leads to a marked increase in the discharge but not in the load because of dense vegetation (Depetris \& Griffin, 1968). The drainage basin of the
Uruguay River, the second largest river in the Rio de la Plata estuary, covers an area of about $365,000 \mathrm{Km}^{2}$ that extends into Uruguay, Argentina, and southern Brazil (Iriondo, 2010; Urien, 1972). Although its usual discharge is about $6000 \mathrm{~m}^{3} \mathrm{~s}^{-1}$, it may attain about $37,000 \mathrm{~m}^{3} \mathrm{~s}^{-1}$ during floods and attain a suspended load of about $100 \mathrm{mg}(\mathrm{mg})$ per liter $\left(\mathrm{mg} \mathrm{l}^{-1}\right)$. The suspended materials are mainly clay and silts whereas the bed load is made up of fine-grained siliceous sands (Quesada, 2019). A complex delta developed in the middle of the valley and open bays were formed in estuarine areas. The southern bank is made up of silt whereas the northern bank consists of sand. In the Uruguay basin the climate is temperate whereas in the Paraná basin it is tropical. The outermost part of the estuary is exposed to episodic storms from the $\mathrm{S}$ and $\mathrm{SE}$, and to floods triggered during strong El Niño Southern Oscillation (ENSO) events (Isla, 2008). The estuary shows an asymmetrical configuration (Fig. 2), it is dominated by the Paraná River and has a NW-SE general trend. Following the flow direction, the denomination of its "left" and "right" margins or banks is hereafter used instead of intermediate cardinal points. The left margin displays all the main sedimentary environments (geoforms), whereas the right margin shows the meandering perambulations of the Río Paraná that reworked the recent sedimentary accumulations. Many of these bedforms are related to the sea-level variations of the last 6000 years BP 
Fig. 1 Location of the study area in South America. Note that the large drainage basin of the Paraná River covers an area of about $3 \times 10^{6} \mathrm{Km}^{2}$
Fig. 2 Main geographical characteristics of the inner and eastern parts of Río de la Plata Estuary. The Samborombón Bay (SB) and Barra del Indio are enhanced (Colombo et al., 2014a, modified)
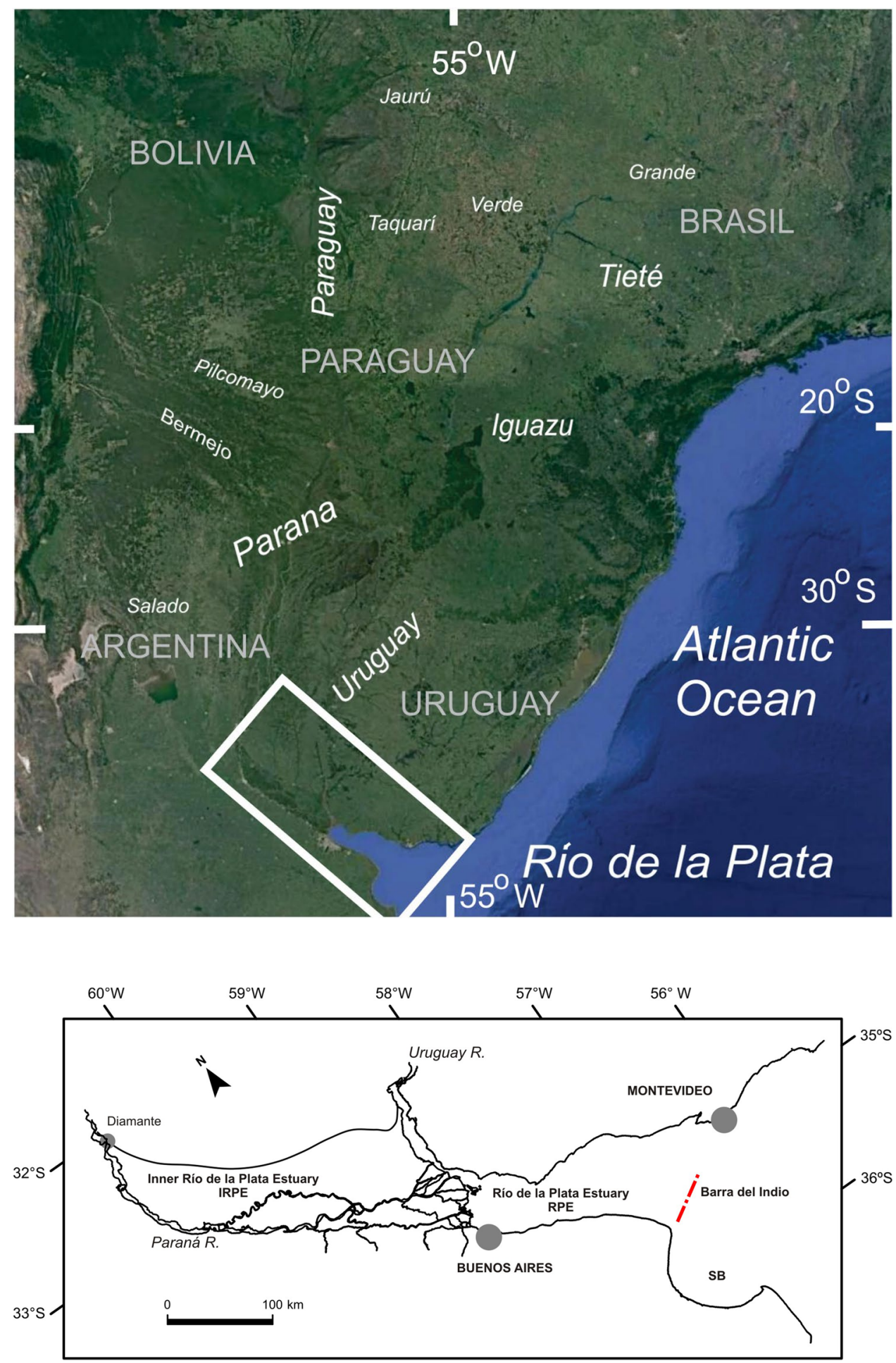

(Prieto et al., 2017) and their fluctuations (few meters) have been studied (Cavallotto et al., 2020; Cellone et al., 2016; Escobar et al., 2004; Isla, 1989; Isla \& Espinosa, 2021). The Paraná delta currently progrades (Schuerch et al., 2016) at a rate of $1.52-1.74 \mathrm{~cm}$ per day $\left(\mathrm{cm} \mathrm{day}^{-1}\right)$. The sedimentary infill of the inner part of the IRPE has been the subject of numerous studies (Cavallotto et al., 2004, 2005; Colombo et al., 2000, 2007; Iriondo, 2010; Luengo et al., 2021; Parker et al., 2008). Recent contributions (Colombo et al., 2014a, 2014b; Milana \& Kröhling, 2015) have provided new insights into the sedimentary infill of the IRPE. Thus, the present study offers new chronological data in an attempt to further our knowledge of the main geoforms in the presentday distribution of the sedimentary infill of the IRPE. 


\subsection{Geological setting}

The oldest Precambrian materials from southwestern Gondwana crops out along the northern bank of the Rio de la Plata Estuary. The estuary is in the area where the Río de la Plata Craton, which constitutes the regional basement, crops out (Rapela et al., 2007; Sánchez-Bettucci et al., 2009; Martínez \& Rojas, 2013; Rosello et al., 2018). The main NNW-SSE lineation is inherited from the Gondwana structures (Dalla Salda, 1999; Dalla Salda, et al., 1988). During the Miocene, the present Rio de la Plata was flooded as it extended upstream along the Paraná River. This is the so-called entrerriense transgression (Del Rio et al., 2018). Along the Pliocene and Pleistocene, westerly winds blew across the Pampean plains depositing silty sands and loess on both sides of the Rio de la Plata estuary. The Upper Pleistocene transgression is characterized by several outcrops along the Río de la Plata (Brunetto et al., 2015; Cavallotto et al., 2005; Isla et al., 2000; Martinez et al., 2016; Martínez et al., 2001). During the maximum glaciation (about 18,000 years BP), the former Paraná River ran across the northern side of the valley close to the present Uruguayan coast (Cavallotto et al., 2005) whereas a secondary river was assumed to drain the Samborombón Bay sector (Fig. 2, SB). The Holocene transgression also affected both banks of the Río de la Plata, i.e. the Uruguayan coast displays several outcrops (Martínez \& Rojas, 2013). The Samborombón coastal plain has been the subject of different studies using datings of carbonate-rich mollusk shells (Codignotto \& Aguirre, 1993; Isla, 1998). At present, the southern coast of the Rio de la Plata is receding at an average rate of $3.6 \mathrm{~m} \mathrm{year}^{-1}$ (Cellone et al., 2016). In the Samborombón Bay, the coastal recession is significantly less $\left(<1 \mathrm{~m} \mathrm{year}^{-1}\right)$, although there is an increase in wave heights (Codignotto et al., 2011).

\section{Materials and methods}

Although a recent study Colombo et al., (2014a) proposed an evolutionary history of the sedimentary infill of the IRPE, further studies are necessary to complement the data. To obtain new chronological data, the study area was divided into sectors $(\mathrm{K}-\mathrm{T})$ where the main sedimentary environments (geoforms) are well displayed (Fig. 3). The chronology of the MBEC can be determined when the distribution of the palaeo-estuary from new dating has been established. The sandy materials were obtained by means of boreholes drilled manually (about $1.5-2 \mathrm{~m}$ in depth) to select the samples for analysis by Optical Stimulated Luminescence procedures (OSL) at the Geophysics Laboratory of the Silesian University of Technology in Gliwice, Poland. (Cavallotto et al., 2005; Colombo et al., 2014a). Although this method (Hart et al., 2016; Mauz \& Hassler, 2000; Robinson et al., 2005) is usually successful, some problems may be

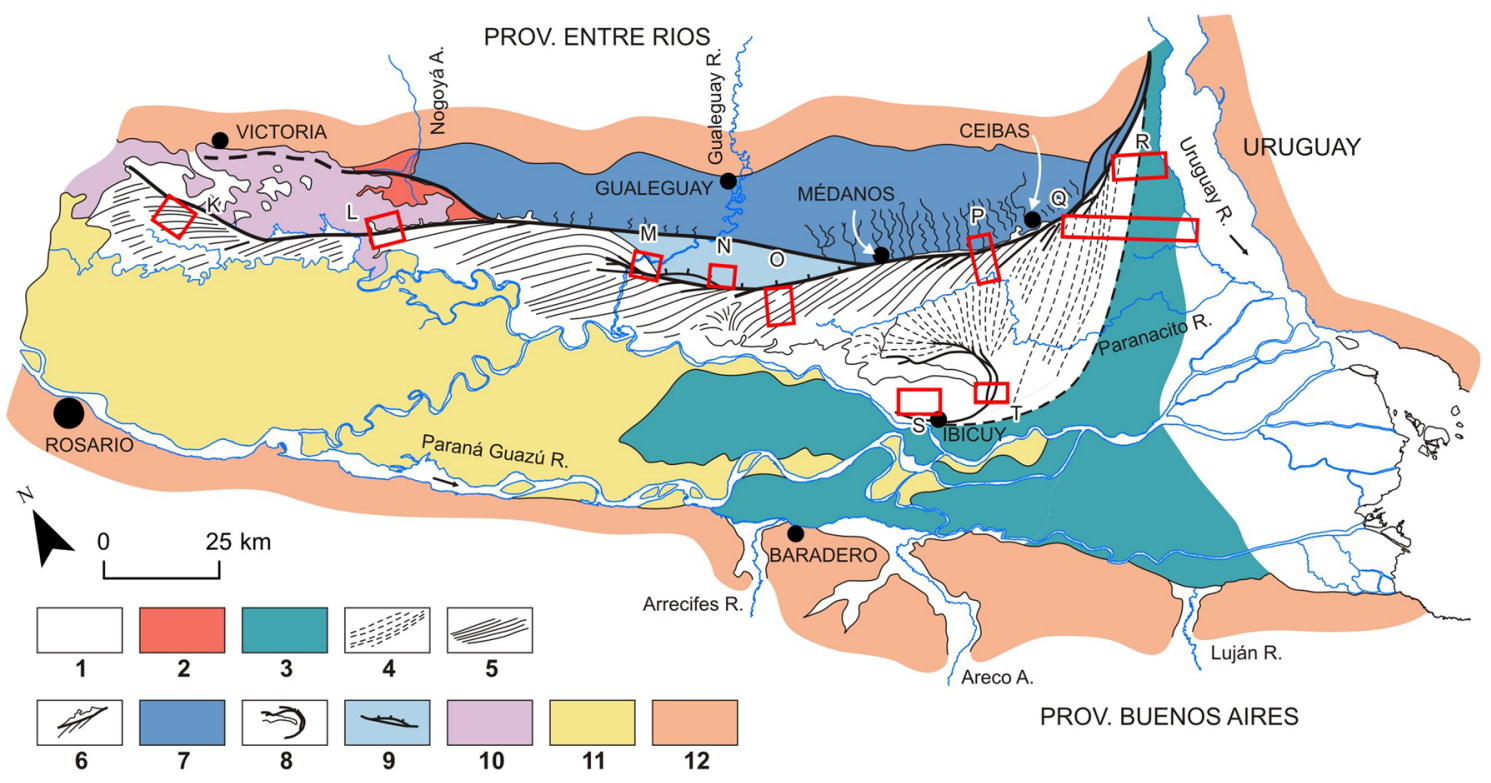

Fig. 3 General distribution of the main sedimentary forms (Colombo et al., 2014a, modified) in the Inner Rio de la Plata Estuary (IRPE). (1) Paraná Delta plain (PRD); The Arrecifes R., Areco A. and Luján R. small estuaries are displayed; (2) Nogoyá A. delta (ND); (3) Tidal flats (TF); (4) Chenier plain (CHP); (5) attached beach ridges (ABR); (6) large coastal estuarine barrier (MBEC) with some washover fans; (7) old coastal lagoon (OCOL) with some washover fans and incised channels; (8) Ibicuy Delta (ID); (9) Gualeguay R. delta (GD); (10) Permanent lagoon and ponds (PL); (11) recent meander belts and levées; (12) PQ, Pre-quaternary substrate (Colombo et al., 2014a, modified). Distribution of the detailed (K, L, M, N, O, P, Q, R, S, T) studied sectors. The dashed line marks the diffuse border between the Tidal Flats (TF) and the Chenier plain (CHP) 
encountered when the data are inconsistent or very scarce because of the local reworking of the materials (Bateman, 2019). The results of ${ }^{14} \mathrm{C}$ dating of shells could also give rise to difficulties owing to the reservoir effects on the shells in an estuarine environment. New photographs of the study area were obtained from a low-flying plane in addition to the original aerial photos supplied by the Instituto Geográfico Militar of Argentina (IGM). The same sampling sites of the old data (Table 1) were revised and verified to determine their precise geographical situation given the unavailability of GPS devices to sample the original materials at that time (Albero \& Angiolini, 1983; Guida \& González, 1984; Codignotto et al., 1992). Most of the new chronological data are obtained from OSL analyses in years Before Present (year BP) whereas the few results of ${ }^{14} \mathrm{C}$ analyses are expressed as uncorrected years (year BP). More than 20 new samples (sands and shells) were collected from selected areas and placed in their respective figures to update our earlier dating. Thus, the samples for OSL analysis were removed from sunlight, wrapped up in a thick black plastic film, and sent to the laboratory. The position of the sampling sites in the figures enhances the chronological value of the data. Boreholes at each sampling site (few meters in depth) were drilled to obtain new samples and thus avoid possible errors of dating due to mixing with surface materials. Given that the boreholes were shallow, the stratigraphical data did not allow
Table 1 Former chronological data (Colombo et al., 2014a, modified)

\begin{tabular}{|c|c|c|c|c|c|c|c|}
\hline Area & South Lat & West Long & $\mathrm{H}$ & $\begin{array}{l}{ }^{14} \mathrm{C} / \mathrm{OSL} \\
\text { Dating }\end{array}$ & Geoform & Mt & Reference \\
\hline 1.1 & $33^{\circ} 11^{\prime} 57.91^{\prime \prime}$ & $59^{\circ} 33^{\prime} 25.39^{\prime \prime}$ & 5 & $6030 \pm 140(b)$ & Spit & Sh & Alb. 83 \\
\hline 1.2 & $33^{\circ} 12^{\prime} 10.35^{\prime \prime}$ & $59^{\circ} 33^{\prime} 12.63^{\prime \prime}$ & 5 & $5680 \pm 110(b)$ & Spit & Sh & Alb. 83 \\
\hline 1.3 & $33^{\circ} 12^{\prime} 09.55^{\prime \prime}$ & $59^{\circ} 33^{\prime} 07.88^{\prime \prime}$ & 5 & $5620 \pm 110(b)$ & MBEC & Sh & Gd. 84 \\
\hline 2.1 & $33^{\circ} 12^{\prime} 34.23^{\prime \prime}$ & $59^{\circ} 33^{\prime} 35.84^{\prime \prime}$ & 5 & $5690 \pm 170(b)$ & $\mathrm{ABR}$ & Sh & Cav.05 \\
\hline 2.2 & $33^{\circ} 12^{\prime} 36.25^{\prime \prime}$ & $59^{\circ} 33^{\prime} 27.27^{\prime \prime}$ & 5 & $5871 \pm 42(\mathrm{v})$ & $\mathrm{ABR}$ & Sh & Cav.05 \\
\hline 3.1 & $33^{\circ} 13^{\prime} 08.85^{\prime \prime}$ & $59^{\circ} 32^{\prime} 31.73^{\prime \prime}$ & 5 & $5760 \pm 110(b)$ & $\mathrm{ABR}$ & Sh & Gd. 84 \\
\hline 3.2 & $33^{\circ} 13^{\prime} 04.47^{\prime \prime}$ & $59^{\circ} 32^{\prime} 35.38^{\prime \prime}$ & 5 & $5610 \pm 110(b)$ & ABR & Sh & Gd. 84 \\
\hline BL1 & $33^{\circ} 12^{\prime} 31.11^{\prime \prime}$ & $59^{\circ} 31^{\prime} 49.10^{\prime \prime}$ & 4.5 & $6360 \pm 80(v)$ & OVF & $\mathrm{Wb}$ & \\
\hline 4.1 & $33^{\circ} 13^{\prime} 10.29^{\prime \prime}$ & $59^{\circ} 31^{\prime} 51.84^{\prime \prime}$ & 4 & $5680 \pm 110(b)$ & MBEC & Sh & Gd. 84 \\
\hline 4.2 & $33^{\circ} 13^{\prime} 52.76^{\prime \prime}$ & $59^{\circ} 25^{\prime} 19.59^{\prime \prime}$ & 2.5 & $5510 \pm 90(\mathrm{~b})$ & GD & Sh & Am. 09 \\
\hline 4.3 & $33^{\circ} 13^{\prime} 53.77^{\prime \prime}$ & $59^{\circ} 25^{\prime} 20.55^{\prime \prime}$ & 1 & $7450 \pm 80(b)$ & GD & Sh & Am. 09 \\
\hline 5.1 & $33^{\circ} 18^{\prime} 01.42^{\prime \prime}$ & $59^{\circ} 25^{\prime} 09.04^{\prime \prime}$ & 5 & $5785 \pm 35(\mathrm{v})$ & GD & Sh & Col. 014 \\
\hline 5.2 & $33^{\circ} 13^{\prime} 31.72^{\prime \prime}$ & $59^{\circ} 25^{\prime} 20.49^{\prime \prime}$ & 3.5 & $5690 \pm 70(b)$ & GD & Sh & Am. 09 \\
\hline 6 & $33^{\circ} 13^{\prime} 45.22^{\prime \prime}$ & $59^{\circ} 28^{\prime} 03.57^{\prime \prime}$ & 4.5 & $5720 \pm 110(b)$ & GD & Sh & Gd. 84 \\
\hline 7 & $33^{\circ} 16^{\prime} 10.32^{\prime \prime}$ & $59^{\circ} 22^{\prime} 42.82^{\prime \prime}$ & 5 & $6440 \pm 110(b)$ & GD & Sh & Cdg.92 \\
\hline 8.1 & $33^{\circ} 25^{\prime} 10.06^{\prime \prime}$ & $58^{\circ} 57^{\prime} 46.69^{\prime \prime}$ & 4.5 & $5530 \pm 110(b)$ & OCOL & Sh & Cdg.92 \\
\hline 8.2 & $33^{\circ} 25^{\prime} 19.94^{\prime \prime}$ & $58^{\circ} 57^{\prime} 50.00^{\prime \prime}$ & 4.5 & $5490 \pm 110(b)$ & OCOL & Sh & Cdg.92 \\
\hline 8.3 & $33^{\circ} 24^{\prime} 48.70^{\prime \prime}$ & $58^{\circ} 57^{\prime} 41.16^{\prime \prime}$ & 4.5 & $5410 \pm 110(b)$ & OCOL & Sh & Cdg.92 \\
\hline 8.4 & $33^{\circ} 24^{\prime} 40.93^{\prime \prime}$ & $58^{\circ} 58^{\prime} 12.49^{\prime \prime}$ & 4.5 & $5280 \pm 100(b)$ & OCOL & Sh & Cdg.92 \\
\hline 9 & $33^{\circ} 31^{\prime} 55.38^{\prime \prime}$ & $58^{\circ} 55^{\prime} 37.86^{\prime \prime}$ & 2.5 & $2530 \pm 35(\mathrm{v})$ & $\mathrm{ABR}(\mathrm{r})$ & Sh & Cav.05 \\
\hline 10 & $33^{\circ} 43^{\prime} 32.14^{\prime \prime}$ & $59^{\circ} 01^{\prime} 05.84^{\prime \prime}$ & 3 & $2820 \pm 160(p)$ & DltaFrt (r) & $\mathrm{Sd}$ & Cav.05 \\
\hline 11 & $33^{\circ} 29^{\prime} 58.65^{\prime \prime}$ & $58^{\circ} 40^{\prime} 23.81^{\prime \prime}$ & 2 & $1902 \pm 41(\mathrm{v})$ & Chenier & Sh & Cav.05 \\
\hline $\begin{array}{l}12.1 \\
12.2\end{array}$ & $\begin{array}{l}33^{\circ} 29^{\prime} 26.54^{\prime \prime} \\
33^{\circ} 29^{\prime} 27.59^{\prime \prime}\end{array}$ & $\begin{array}{l}58^{\circ} 40^{\prime} 45.24^{\prime \prime} \\
58^{\circ} 40^{\prime} 47.22^{\prime \prime}\end{array}$ & 4.54 .5 & $\mathbf{2 5 0 2} \pm \mathbf{8 5}(\mathbf{p}) 1690 \pm 83(\mathrm{v})$ & $\begin{array}{l}\text { Chenier } \\
\text { Chenier(r) }\end{array}$ & $\begin{array}{l}\mathrm{Sd} \\
\mathrm{Sd}\end{array}$ & $\begin{array}{l}\text { Cav.05 } \\
\text { Cav.05 }\end{array}$ \\
\hline 13 & $33^{\circ} 30^{\prime} 59.53^{\prime \prime}$ & $58^{\circ} 39^{\prime} 23.00^{\prime \prime}$ & 1.8 & $1770 \pm 41(v)$ & Chenier & Sh & Cav.05 \\
\hline 14 & $33^{\circ} 38^{\prime} 20.96^{\prime \prime}$ & $58^{\circ} 39^{\prime} 18.00^{\prime \prime}$ & 1.5 & $<410(p)$ & Chenier(r) & $\mathrm{Sd}$ & Cav.05 \\
\hline
\end{tabular}

The values obtained are from samples collected at different sectors $(\mathrm{K}-\mathrm{T})$; Sector $\mathrm{M}$, sites: 1.1, 1.2, 1.3, 2.1, 2.2, 3.1 3.2, 4.1, BL-1; Sector N, sites: 4.2, 4.3, 5.1, 5.2, 6, 7; Sector P, site: 10; Sector P, sites: 11, $12.1,12.2,13,14$. H: elevation in meters

Geoform: MBEC; Spits related to the MBEC; ABR; $O V F$ overflow fans, GD Gualeguay delta, $O C O L$ Old Coastal Lagoon, DltaFrt delta front, Chenier, $r$ ridge, $s$ swale, Mt. materials: Sh shells, $S d$ sands: $W b$ whale bones. Reference: Alb. 83, Albero \& Angiolini, 1983); Am. 09, Amato and Silva Busso (2009), Gd. 84, Guida and González (1984), Cdg. 92, Codignotto et al. (1992), Cav. 05, Cavallotto et al. (2005), Col. 014a, Colombo et al. (2014a)

In bold, Optically Stimulated Luminiscence $(O S L)$ data; The ${ }^{14} \mathrm{C}$ data are in non-corrected years Before Present (y BP); (b) INGEIS Laboratory, Buenos Aires University; (v) Van Der Graaf laboratory, University of Utrecht, Netherlands; (p) Geophysics laboratory. Silesian University of Technology, Gliwice, Poland 
us to generate new cross sections and figures. The dating of the remains of whale carcasses (Eubalaena australis) was used only in few cases to avoid contamination from unnecessary exposure to the elements. To calculate the speed of accumulation of the IRPE sedimentary infill, we use different equations (Orfeo, 1995; Vanoni, 1975). These concern the different relationships between the discharge, load, and variable rates of retention.

\section{Differentiated geoforms}

Our "geoform" denomination concerns the present geomorphological characterization (Colombo et al., 2014a, 2014b) of the different sedimentary environments formed in the IRPE considered as a large depositional system (Fisher \& McGowen, 1967). Insights into the distribution of the main geoforms in the IRPE are given in Fig. 3.

\subsection{Main forms}

The most studied and the most widely sampled geoforms include the long coastal estuarine barrier (MBEC), the old coastal lagoon (OCOL), the strandplain of attached beach ridges (ABR), the Gualeguay delta (GD), the chenier plain (CHP), and the Ibicuy Delta (ID). By contrast, the Tidal flats (TF), the Paraná delta, (PRD) and small deltas and estuaries (Fig. 3) have not yet been fully sampled.

\subsubsection{Long coastal estuarine barrier (MBEC)}

The main estuarine barrier on the left side of the IRPE (Fig. 3) is composed of fine to medium-grained quartz-dominated sands with sparse fragments of shells. Some remains of former barriers were recognized from aerial views. The MBEC stretches for about $300 \mathrm{~km}$ from the Uruguay River to the surroundings of the town of Victoria. It consists of different sectors that display a variety of semi-curved segments with a width of 200-700 m and a mean primary elevation of 5-7 $\mathrm{m}$ above mean sea-level (msl). Nevertheless, this elevation rises locally to $11-15 \mathrm{msl}$ where large aeolian dunes are present. The MBEC prograded SSE as shown by Ground Penetrating Radar surveys (Colombo et al., 2007). Remains of a coastal estuarine barrier are arranged obliquely to the pre-Quaternary coast from Rincón de Nogoyá (mouth of Nogoyá Arroyo) to Victoria. These remains are differentiated by the straight alignment that marks the eastern boundary of the Nogoyá delta and continues in the direction of Victoria. The former MBEC is currently masked by the permanent lagoon (PL) and small ponds near Victoria. The area is fed by small creeks characterized by their vegetated levées prograding into the PL. These levées display a morphology of prograding mouth bars in a "goose-foot-type" deltaic configuration given the continuous supply of water and sediments in ponded areas. The levées developed under climatic conditions that favored the growth of trees and bushes. In the sector of the Nogoyá Arroyo is a curved segment of the MBEC to the SE, which stretches to the Victoria-Rosario motorway bridge. Another curved segment, which is located to the SSE of the Gualeguay River, reaches the Estancia La Calera to the SW of the town of Gualeguay.

\subsubsection{Old coastal lagoon (OCOL)}

Since the MBEC was generated with an SE-NW alignment $(6-30 \mathrm{~km})$ from the pre-Quaternary coast, it closed off a flooded area which occupies a large extension of about 780 $\mathrm{km}^{2}$. This is the old coastal lagoon (OCOL) that extends from Ceibas to the Nogoyá delta (Fig. 3). The OCOL, which was filled with mud-rich deposits, may be divided into two areas: (1) an area that is defined by its gentle slope towards the NE, with sparse traces of isolated channel creeks; and (2) an area located behind the main MBEC, which displays numerous meandering creek traces that locally cross the MBEC and several sand-dominated wash over fans.

\subsubsection{Attached beach ridges (ABR)}

The IRPE displays an extended (about $170 \mathrm{~km}$ ) set of attached beach ridges (ABR) on the southern side of the MBEC (Fig. 3). These ridges make up a large strandplain (of about $2400 \mathrm{Km}^{2}$ ) with numerous alignments composed of well-sorted fine and very-fine quartz-dominated sands. Locally there are shell accumulations (Erodona mactroides) that accentuate the primary cross bedding (Cavallotto et al., 2004, 2005). The beach ridges (about 220 in number), which have an average extension of $4-15 \mathrm{~km}$ and a maximum of $20 \mathrm{~km}$, are separated from one another by a mud-dominated lowland that attains a width of $1 \mathrm{~km}$ locally. These geoforms have been masked by recurrent flooding of the Paraná River.

\subsubsection{Chenier plain (CHP)}

The cheniers in the area (Fig. 3) between the Ibicuy Delta (ID) and Ceibas are composed of fine-grained sand in smooth convex-up bodies bracketed by mud flats (Augustinus, 1989; Otvos, 2000; Otvos \& Price, 1979). They are usually isolated with lineations that have a fan pattern morphology towards the NE of the ID and a regular spacing and a NE-SW orientation. These features are accentuated by vegetation. Some cheniers contain scattered accumulations of shell fragments dated about 1902-1770 years BP (Cavallotto et al., 2005). 


\subsubsection{Ibicuy delta (ID)}

The village of Ibicuy is in a sand-dominated area $\left(336 \mathrm{~km}^{2}\right)$, which is raised $(2-3 \mathrm{~m})$ above the surrounding plain in the middle of the IRPE (Fig. 3).

The materials are made up of very fine to medium grainsize sand and are arranged in smooth coarsening-upwards sequences in boreholes (2-3 $\mathrm{m}$ in depth) about $4 \mathrm{~km}$ to the $\mathrm{E}$ and ENE of Ibicuy. These findings together with those obtained by the GPR surveys (Colombo et al., 2007, 2014a) provide ample evidence that the sand body originated as a shallow delta exposed to strong winds (sudestadas) from the SSE (Bischoff, 2006).

\subsubsection{Tidal flats (TF)}

The mud-rich deposits to the $\mathrm{S}$ and $\mathrm{W}$ of the ID and to the S of Ceibas occupy wide areas (Fig. 3). Small creeks and ravines, which cross them, are distinguished by their dendritic courses with straight segments and confluences at right angles. These characteristics are enhanced by vegetated levées with Tala trees (Celtis tala). The present distribution of the TF has been affected by the fluvial activity of the Paraná River and its distributaries mainly in the area to the SW of the ID. The boundaries between the tidal flats and the chenier plain are not well defined and are masked by the recurrent flooding of the area due to the sedimentary activities of the Paraná-Uruguay Rivers (PUR) System.

\subsubsection{Paraná delta (PRD)}

Today the delta is made up of fine-grained sand deposits interfingered with silts and muds (Fig. 3) that are transported by numerous distributaries with vegetated levées. These distributaries in the delta front prograde to the RPE and give rise to several islands characterized by prominent levées and a lagoon in the center. The interchannels are muddominated flats with sparse cheniers adjacent to the banks of the Uruguay River. The southern sector of the PRD is currently active, growing at a rate of $40-45 \mathrm{~m}_{\text {year }}{ }^{-1}$ (Marcomini et al., 2018) and attaining about $70 \mathrm{my}^{-1}$ because of the sediment carried by the Paraná River (Depetris \& Griffin, 1968).

\subsubsection{Small deltas and estuaries}

The OCOL near Victoria was influenced by the development of a small Nogoyá Delta (ND) that resulted from the sedimentary activity of the Nogoyá Arroyo (Fig. 3). The surroundings of Gualeguay were dominated by the evolution of a small delta (Gualeguay River Delta, GD). Small ravines also generated minor deltas in the OCOL. Their channels with prominent levées are raised over the average level of permanent waters and are accentuated by their vegetated banks. The right bank of the IRPE (Buenos Aires province) shows small estuaries, one of which displays some minor beach ridges (Fucks et al., 2011) resembling those of the ABR.

\section{Results}

The gradual build-up of the MBEC occurred as the sealevel increased and flooded the former Paraná-Uruguay valley until about 6000 years BP when the sea-level ceased to rise. The barrier continued to grow in longitudinal and transversal directions during the rise in sea-level because of reworked sediments of an earlier barrier with contributions from floods and smaller rivers (Cavallotto et al., 2005; Colombo et al., 2014a, 2014b; Iriondo, 2010). The stillstand occurred after the sea-level rise and resulted in the formation of the MBEC. This barrier was subsequently reworked by storm erosion, modified by local tributaries (Nogoyá A. and Gualeguay R.), wind action (dune fields) or covered by sediments transported by high-energy SSE storms ( $s u d$ estadas). It should be noted that the ages obtained along the MBEC show small differences between the right bank of the Uruguay River and Victoria (around 6000 years BP). The ages in the Gualeguay and Nogoyá deltas are some centuries younger than those of the surrounding areas. Dating provided by OSL confirmed the age of these lithosomes. Some ${ }^{14} \mathrm{C}$ analyses were carried out on shell fragments (Table 2). The progradation rates are calculated bearing in mind that the sedimentary accumulation was generated without significant interruptions.

\subsection{Sector K (Victoria-Rosario bridge)}

The area is in the extension of the MBEC upstream to the NNW (Fig. 4K) where the materials had not been reworked during the construction of the Victoria-Rosario Bridge. The dates of the two samples taken in this area (Table 2) indicate that the sediments had accumulated between (site 587) FPVR 1 (6430 years BP) and (site 588) FPVR 2 (6630 years BP). The progradation rates are as follows: $0.88 \mathrm{~m} /$ year $\left(\mathrm{m}\right.$ year $\left.{ }^{-1}\right)$ and $0.05 \mathrm{~m}_{\text {year }}{ }^{-1}$. The mean progradation rate is $0.35 \mathrm{~m} \mathrm{year}^{-1}$ for the MBEC sector in the innermost part of the Río de la Plata Estuary, which is dominated by fluvial activity.

\subsection{Sector L (Rincón de Nogoyá)}

The area (Fig. 4L), which is slightly raised above the flood plain, is in the MBEC extension upstream to the NNW. It is worth noting that the materials are primary sands (not reworked) that accumulated in a large aeolian dune. 
Table 2 New chronological data

\begin{tabular}{|c|c|c|c|c|c|c|c|}
\hline Site & South Latitude & West Longitude & $\mathrm{D}$ & $\begin{array}{l}{ }^{\mathbf{1 4}} \mathrm{C} / \mathrm{OSL} \\
\text { Dating }\end{array}$ & Geofm & Mt & $\begin{array}{l}\text { Refer- } \\
\text { ences }\end{array}$ \\
\hline 574 & $33^{\circ} 23^{\prime} 35.26^{\prime \prime}$ & $59^{\circ} 12^{\prime} 33.88^{\prime \prime}$ & 1.35 & $4290 \pm 210(b)$ & Spit & $\mathrm{Sd}$ & FRNT 1 \\
\hline 575 & $33^{\circ} 26^{\prime} 41.32^{\prime \prime}$ & $59^{\circ} 13^{\prime} 25.75^{\prime \prime}$ & 0.9 & $3370 \pm 220(b)$ & $\mathrm{ABR}$ & $\mathrm{Sd}$ & FRNT 2 \\
\hline 576 & $33^{\circ} 23^{\prime} 43.67^{\prime \prime}$ & $59^{\circ} 12^{\prime} 57.52^{\prime \prime}$ & 0.8 & $3410 \pm 170(b)$ & MBEC & $\mathrm{Sd}$ & FRNT 3 \\
\hline 577 & $33^{\circ} 23^{\prime} 19.56^{\prime \prime}$ & $59^{\circ} 12^{\prime} 36.42^{\prime \prime}$ & 0.85 & $4740 \pm 280(b)$ & Spit & $\mathrm{Sd}$ & FRNT 4 \\
\hline 578 & $33^{\circ} 22^{\prime} 46.46^{\prime \prime}$ & $59^{\circ} 12^{\prime} 03.88^{\prime \prime}$ & 1.05 & $6830 \pm 330(b)$ & MBEC & $\mathrm{Sd}$ & FRNT 5 \\
\hline 582 & $32^{\circ} 55^{\prime} 54.4^{\prime \prime}$ & $59^{\circ} 55^{\prime} 11.1^{\prime \prime}$ & 1.4 & $4650 \pm 660(b)$ & MBEC & $\mathrm{Sd}$ & FTIGM1 \\
\hline 583 & $32^{\circ} 55^{\prime} 58.6^{\prime \prime}$ & $59^{\circ} 54^{\prime} 58.8^{\prime \prime}$ & 1.7 & $6230 \pm 270(b)$ & MBEC & $\mathrm{Sd}$ & FTIGM2 \\
\hline 584 & $32^{\circ} 56^{\prime} 01.0^{\prime \prime}$ & $59^{\circ} 55^{\prime} 06.6^{\prime \prime}$ & 1.55 & $6940 \pm 430(b)$ & MBEC & $\mathrm{Sd}$ & FTIGM3 \\
\hline 587 & $32^{\circ} 41^{\prime} 18.7^{\prime \prime}$ & $60^{\circ} 17^{\prime} 54^{\prime \prime}$ & 0.9 & $6430 \pm 220(b)$ & MBEC & $\mathrm{Sd}$ & FPVR 1 \\
\hline 588 & $32^{\circ} 41^{\prime} 19.5^{\prime \prime}$ & $60^{\circ} 17^{\prime} 52.6^{\prime \prime}$ & 0.9 & $6630 \pm 720(b)$ & MBEC & $\mathrm{Sd}$ & FPVR 2 \\
\hline 592 & $33^{\circ} 44^{\prime} 06.58^{\prime \prime}$ & $59^{\circ} 07^{\prime} 17.13^{\prime \prime}$ & 1.1 & $3430 \pm 220(b)$ & $\mathrm{Ch}$ & $\mathrm{Sd}$ & FZY 1 \\
\hline 593 & $33^{\circ} 42^{\prime} 07.36^{\prime \prime}$ & $59^{\circ} 09^{\prime} 33.08^{\prime \prime}$ & 1.05 & $4310 \pm 270(b)$ & Levee & $\mathrm{Sd}$ & FZY 2 \\
\hline 594 & $33^{\circ} 41^{\prime} 51.89^{\prime \prime}$ & $59^{\circ} 10^{\prime} 05.28^{\prime \prime}$ & 1.1 & $4440 \pm 280(b)$ & Levee & $\mathrm{Sd}$ & FZY 3 \\
\hline 595 & $33^{\circ} 25^{\prime} 27.48^{\prime \prime}$ & $58^{\circ} 38^{\prime} 48.65^{\prime \prime}$ & 0.4 & $5980 \pm 350(v)$ & MBEC & $\mathrm{Sh}$ & FDE1 \\
\hline 596 & $33^{\circ} 24^{\prime} 51.31^{\prime \prime}$ & $58^{\circ} 34^{\prime} 21.85^{\prime \prime}$ & 1.05 & $695 \pm 59(b)$ & Dune & $\mathrm{Sd}$ & FDE2 \\
\hline 597 & $32^{\circ} 24^{\prime} 54.10^{\prime \prime}$ & $58^{\circ} 35^{\prime} 33.60^{\prime \prime}$ & 0.3 & $5510 \pm 300(v)$ & MBEC & Sh & FDE 3 \\
\hline 598 & $33^{\circ} 42^{\prime} 22.16^{\prime \prime}$ & $59^{\circ} 01^{\prime} 38.13^{\prime \prime}$ & 1 & $533 \pm 39(b)$ & Dune & $\mathrm{Sd}$ & FEEBY 1 \\
\hline 599 & $33^{\circ} 42^{\prime} 14.94^{\prime \prime}$ & $59^{\circ} 01^{\prime} 28.12^{\prime \prime}$ & 0.75 & $2120 \pm 130(b)$ & DltaFrt & $\mathrm{Sd}$ & FEEBY2 \\
\hline 600 & $33^{\circ} 42^{\prime} 11.08^{\prime \prime}$ & $59^{\circ} 02^{\prime} 03.21^{\prime \prime}$ & 1.05 & $3660 \pm 220(b)$ & DltaFrt & $\mathrm{Sd}$ & FEEBY3 \\
\hline
\end{tabular}

The values obtained are from samples collected in different sectors (K-T) in the IRPE (Fig. 3)

Geofm main geoforms: ABR; MBEC Spits associated with the MBEC, Ch ID main channel, Levee ID levee, DltaFrt ID Delta Front, Mt. materials: $S d$ sands, Sh shells. References: FRNT estancia Nueva Totora, FTIGM Torre Instituto Geográfico Militar, FPVR Puente Victoria-Rosario, FAZZT Estancia La Azotea, FZY Ibicuy, FDE Estancia Don Elías, FEEBY Railway station "Libertador General San Martín"

Sector K, sites: 587, 588; Sector L, sites: 582, 583, 584; Sector O, sites: 574, 575, 576, 577, 578; Sector R, sites: 595, 596, 597; Sector S, sites: 592, 593, 594; Sector T, sites: 598, 599, 600. Precise location of boreholes obtained from GPS (Garmin 60CSx) data. D, borehole depth in meters below the ground surface; data from ${ }^{14} \mathrm{C}$ analyses (in bold) were performed at the Van der Graaf Laboratory, University of Utrecht (v). The OSL analyses (b) were carried out at the Geophysics Laboratory, Silesian University of Technology (Gliwice, Poland)

Three samples FTIGM 1 (site 582) FTIGM 2 (site 584) and TIGM 3 (site 583) show that the materials had been deposited at 4650 years BP, 6940 years BP and 6230 years $\mathrm{BP}$, respectively. The progradation rates of the MBEC are as follows: 5.52 and $5.34 \mathrm{~m} \mathrm{year}^{-1}$. The average growth rate is about $5.43 \mathrm{~m}_{\text {year }}{ }^{-1}$.

\subsection{Sector M (Estancia La Calera)}

This corresponds to the local end of the MBEC progradation to the NNW. The samples were collected in the ABR sets and in the MBEC. Some bones corresponding to an articulated whale carcass (6360 years BP) were found (site BL-1, Fig. 4M) in the sandy deposits of overwash fans. Other samples were collected in the ND but one sample (5785 years BP) forms part of the shell accumulation (Fig. $5 \mathrm{~N}$ ) close to the main buildings of the Estancia La Conchera de Flores.

\subsection{Sector $\mathbf{O}$ (Estancia Nueva Totora)}

The area (Fig. 5O) includes a spit attached to the MBEC, a small portion of the Gualeguay Delta (GD) and a sector of the ABR. One sample (site 575), which was collected from the beach ridges (ABR) attached to the MBEC, was dated at 3370 year BP. These dates provide valuable insights into the growth rate of the beach ridges. The spit was sampled at two locations (site 574, site 576) yielding dates of 4290 years BP and 3410 years BP, respectively. In the MBEC, another sample (site 577) gave a date of 4740 years BP. The sample (site 578) from a former coastal lagoon indicates that it was active at 6830 years BP. At the Estancia Nueva Totora (Table 2), the dating of two samples (FRNT 2; FRNT 3 ) provide the following rates of beach ridge progradation: $62 \mathrm{~m} \mathrm{year}^{-1}$ and $56 \mathrm{~m} \mathrm{year}^{-1}$. The mean rate is about 120 $\mathrm{m}$ year $^{-1}$ for the main segment of the beach ridges (ABR) attached to the MBEC. In the spit area, the difference in age of the two samples (FRNT 1 and FRNT 3) gives the 

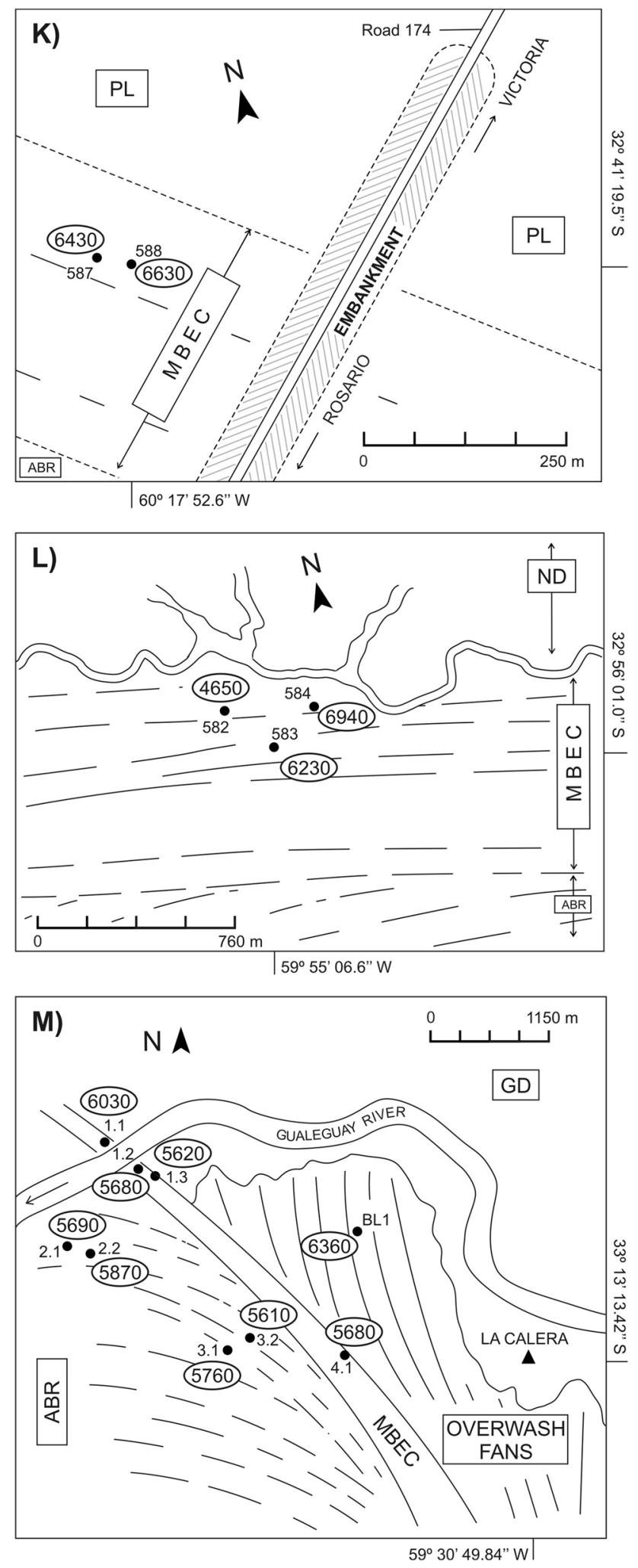

Fig. 4 K. Sector K. Bridge of Victoria-Rosario National Road 174. Distribution of samples. The points are the sampling sites, whereas the encircled numbers are the absolute (y BP) dating values. L.-Sector L. Rincón de Nogoyá. Distribution of samples. M.-Sector M. Estancia La Calera. Distribution of samples and whale remains (BL1) following values: maximum of 920 year, minimum of 840 year and mean of 880 year. This indicates that the spit grew at rates: $0.45 \mathrm{~m}_{\text {year }}{ }^{-1}, 0.50 \mathrm{~m}_{\text {year }}{ }^{-1}$ and $0.47 \mathrm{~m}_{\text {year }}{ }^{-1}$. In the sector of the MBEC, the difference in age of the two samples (FRNT 1; FRNT 4) provides the following values: maximum of 520 year, minimum of 380 year and mean of 450 year. This results in growth rates of $0.66 \mathrm{~m} \mathrm{year}^{-1}$ of $0.77 \mathrm{~m}$ year $^{-1}$ and of $0.90 \mathrm{~m}$ year $^{-1}$. In the OCOL, the dating of one sample (FRNT 5) yields an age of 6830 year BP, which indicates that the sedimentary infill of the OCOL was active at that time.

\subsection{Sector $P$ (Médanos)}

The samples (Fig. 5P), which were collected in the OCOL (at sites 8.1, 8.2, 8.3 and 8.4), gave ages of 5530-5280 years BP. The shell samples probably correspond to the materials reworked from the primary accumulations in the MBEC. One sample (site 9) in the ABR provides an age of 2530 years BP. An entire whale carcass was found to the south of the village of Médanos (site BL-4) but the dating was of no significance.

\subsection{Sector Q (Estancia la Azotea area)}

The samples (Fig. 5Q) were collected along a rough track crossing the chenier ridges suggesting ages of 2502 years BP, 1690 years BP, 1902 years BP and 1770 years BP. Thus, the growth rates of the cheniers in recent times are as follows: $1.62 \mathrm{~m}$ year $^{-1}$ and $1.40 \mathrm{~m} \mathrm{year}^{-1}$. The mean is 1.65 $\mathrm{m}$ year $^{-1}$ for the sector of the MBEC under study. The cheniers, which are displayed as raised chenier plains (CHP), are distributed in the form of two patterns: (see Figs. 5Q, $6 \mathrm{R}$ ) one with closely spaced ridges (like the ABR ridge sets) that make up the Upper chenier plain (UCHP), and the other where the ridges are separated by hundreds of meters, constituting the Lower chenier plain (LCHP).

\subsection{Sector R (Estancia Don Elías)}

The samples were collected (Fig. 6R) in a mud dominated area with shell accumulations (Erodona mactroides). The ${ }^{14} \mathrm{C}$ analyses give ages of 5980 years BP (site 595) and of 5510 year BP (site 597). In an area with a large accumulation of aeolian sands, another sample (site 596) was collected, yielding an age of 695 year BP. The ${ }^{14} \mathrm{C}$ analyses of the two samples (Table 2) with shell remains (site 595-FDE 1 and site 597-FDE 3 ) indicate the progradation rates of 3.79 $\mathrm{m}_{\text {year }}{ }^{-1}$, and $4.69 \mathrm{~m}_{\text {year }}{ }^{-1}$. The mean is 4.22 myear $^{-1}$ for the development of the Coastal Lagoon. 
Fig. 5 N-Sector N. Estancia La Conchera de Flores. Sample distribution and whale remains (BL-2, BL-3). The points are the sampling sites, whereas the encircled numbers are the absolute (y BP) dating values. O-Sector O. Estancia Nueva Totora. Sample distribution. P.-Sector P. Médanos area. Distribution of samples and whale remains (BL-4). Note the railway line that crosses Médanos. Q-Sector Q. Ceibas. Estancia La Azotea area. Note the absence of the boundary between the Upper (CHP) and the Lower chenier plain (LCHP). This also applies to the Tidal Flats (TF)

\subsection{Sector S (Ibicuy)}

Samples were collected near the village of Ibicuy (Fig. 6S). The areas were selected to elucidate the growth rate of the Ibicuy Delta (ID). At site 592, the sand-dominated materials are present along the main channel of the Ibicuy Delta, which was active at 3430 years BP. Other samples that were collected on the right levee of the main channel of the ID suggest ages of 4440 years BP (site 594) and 4310 year BP (site 593), which indicate the following progradation rates: $7.23 \mathrm{~m} \mathrm{year}^{-1}, 7.78 \mathrm{~m} \mathrm{year}^{-1}$ and $8.43 \mathrm{~m} \mathrm{year}^{-1}$, respectively.

\subsection{Sector T (“Libertador General San Martín” Railway station)}

This area displays different progradation stages (Table 2) of the Ibicuy Delta front covered by recent aeolian dunes locally (Fig. 6T). Thus, one location (site 599), which corresponds to the upper part of the deltaic front, could have been active up to 2120 years BP. An older deltaic front (site 600) was active at 3660 years BP. However, in an area (site 598) which is characterized by aeolian dunes, the date of 533 years BP suggests that the dunes were active in recent times. The OSL dates of the two samples (site 599-FEEBY 2 and site 600-FEEBY 3) of the ID front give the following progradation rates: $0.62 \mathrm{~m}$ year ${ }^{-1}$ and $0.59 \mathrm{~m} \mathrm{year}^{-1}$. The mean is about $0.58 \mathrm{~m} \mathrm{year}^{-1}$ for the ID.

\section{Discussion}

The IRPE sedimentary infill was produced by the contribution of the main fluvial and fluvio-marine sedimentary environments (Fig. 7). The following considerations should be highlighted:

1. In our earlier works (Cavallotto et al., 2005; Colombo et al., 2014a, 2014b) we traced the evolution of the IRPE from the last eustatic maximum. Note that there is a marked difference between the two banks of the IRPE. This difference is due to the orientation of the bank that was controlled by the interaction of fluvial and marine processes that prevailed along the left and right
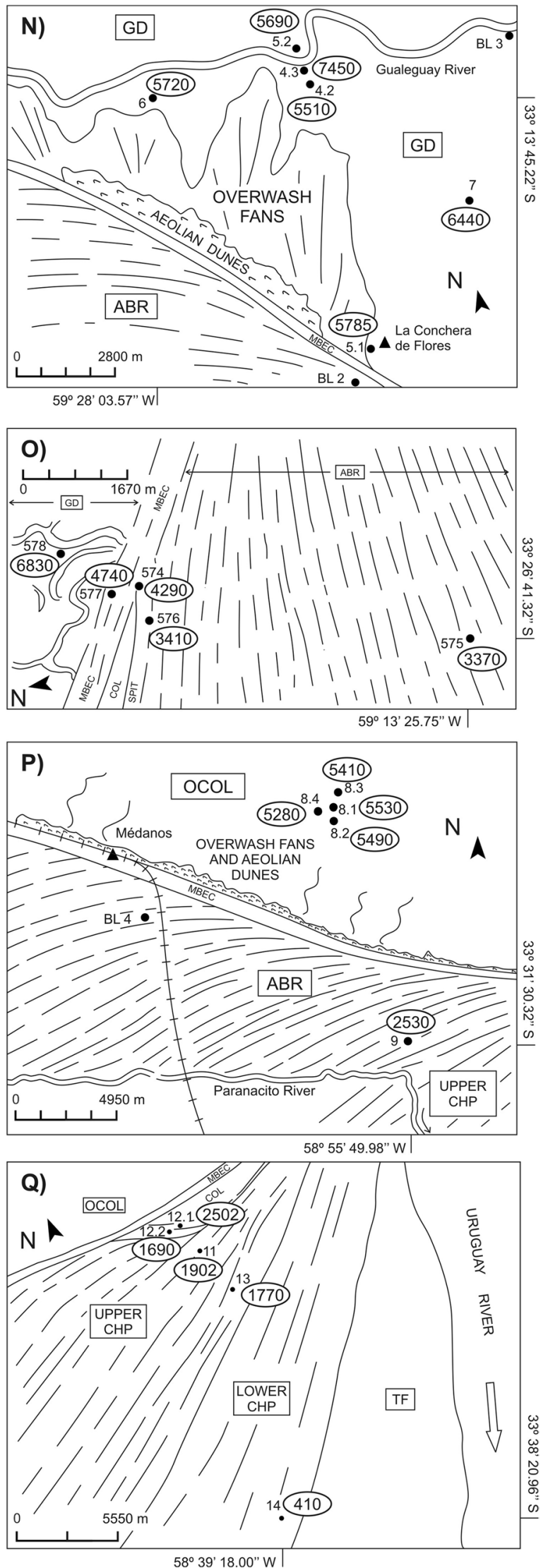

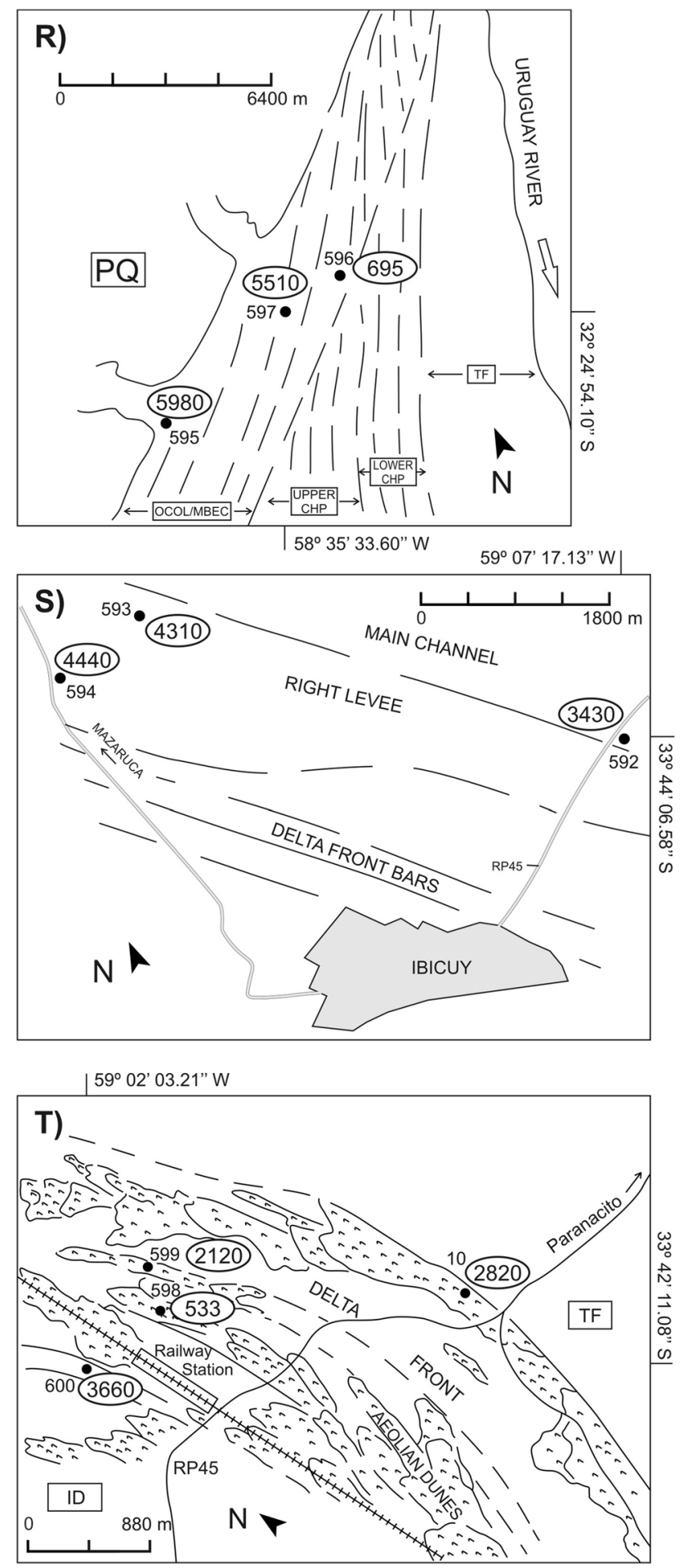

Fig. 6 R-Sector R. Estancia Don Elías. Distribution of samples. The points are the sampling sites, whereas the encircled numbers are the absolute (y BP) dating values. The MBEC and the OCOL are not clearly distinguishable. Note the absence of the marked boundary (Dashed line in Fig. 3) between the Upper (UCHP) and Lower chenier plain (LCHP). In the case of Tidal Flats (TF) the boundary is also absent. S.-Sector S. Surroundings of Ibicuy. Distribution of samples. Note that the delta front bars of the ID shifted to the north-west. T.-Sector T. Railway station "Libertador General San Martín". Distribution of samples.. The main delta front bars were covered by aeolian dunes banks. Moreover, these processes were conditioned by sea-level variations that led to the progradation of the present Paraná River delta. The extensive flooding of the IRPE commenced in the proximity of the "Barra del Indio" (Fig. 2) to the south of Montevideo (Cavallotto et al., 2004; Parker et al., 2008) with a current depth of about $7 \mathrm{~m}$, attaining its maximum extension near Victoria-Diamante at about 6000 years BP. The flooding of the area (about $475 \mathrm{~km}$ long) occurred over 3000 years (Isla, 1989) at a rate of about $4 \mathrm{~mm} /$ year $\left(\mathrm{mm} \mathrm{year}^{-1}\right)$. It resulted in an intensive reworking of earlier deposits and in the sedimentary supply from the PUR system, which contributed to the gradual growth of the MBEC on the IRPE left bank. Moreover, the evolution of the fluvial systems produced the reworking of previously accumulated sediments on the right bank of the IRPE (Fucks et al., 2011). This process was controlled by the evolution (progradation-retrogradation) of the MBEC. As the sea-level dropped, the MBEC was exposed to the SSE winds (sudestadas) and acted as a prominent levee. Thus, the MBEC grew longitudinally upstream along the Paraná River, and prograded transversally along its left bank (Colombo et al., 2007). The gradual generation of the MBEC may be attributed to the Holocene sea-level rise and to the meteorological tides in the paleovalley of the Paraná River, attaining a maximum elevation of about 5-6 msl. The water level of the estuary reached its peak at about 6000 years BP as is evidenced in other places such as Samborombón Bay (SB in Fig. 2) sector (Luengo et al., 2021). The barrier showed no evidence of successive sedimentary stages caused by fluvial and flood reworking on the left side of the estuary.

2. The PUR system (Fig. 8A, B) was exposed to the ENSO activities because of atmospheric interconnections with the Atlantic region (Cazes-Boezio et al., 2003; García $\&$ Mechoso, 2005). However, ENSO periodicity has not yet been clearly established because of the ongoing controversy over whether the periodicities are decadal, interdecadal or bidecadal (Tedeschi \& Collins, 2016). In a context with no significant sea-level variations, the development of the Nogoyá Delta (ND) which was coeval with the generation of the MBEC 4 (Fig. 9C) strongly suggests a rapid and random increase in precipitation in the Nogoyá Arroyo drainage basin probably because of an unusual ENSO activity. However, further research on the diverse parameters and their modeling in the areas affected by variations in the periodicities of the ENSO effects is warranted (Kanner et al., 2013; Markgraf \& Diaz, 2000). The amplitude and activities of ENSO undergo variations over time from tropical to austral regions in the Pacific.

3. The ABR evolved continuously between the MBEC positions 4 and 10. Numerous and parallel linear sets 

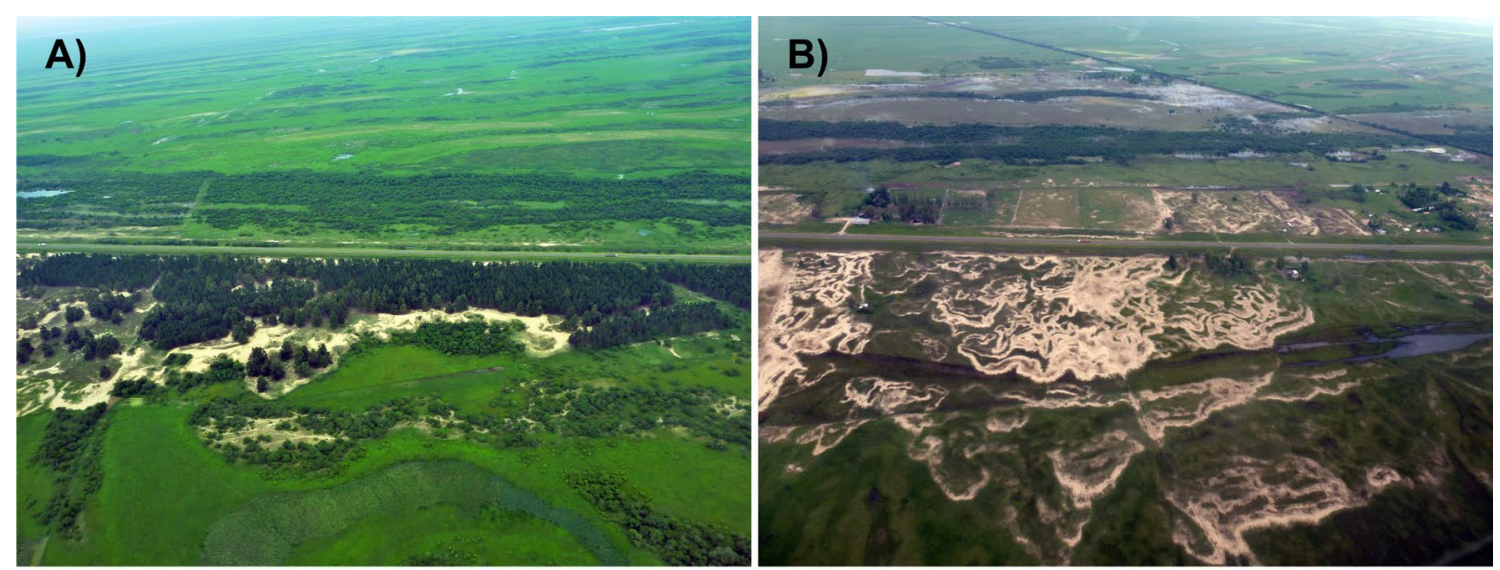

\section{C)}

D)

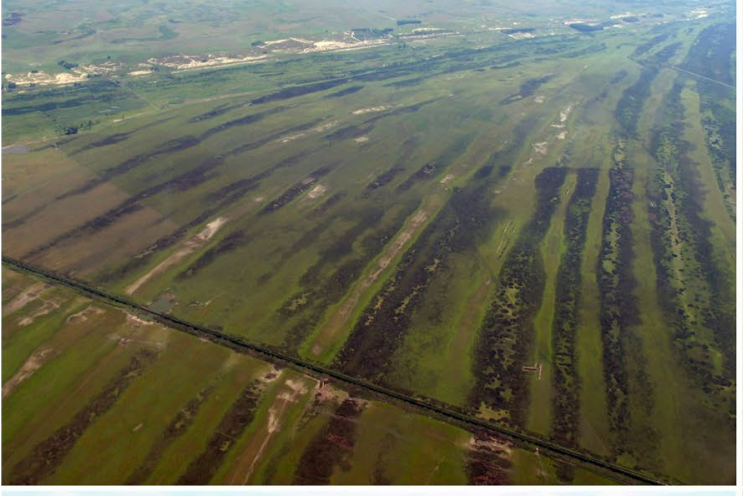

E)
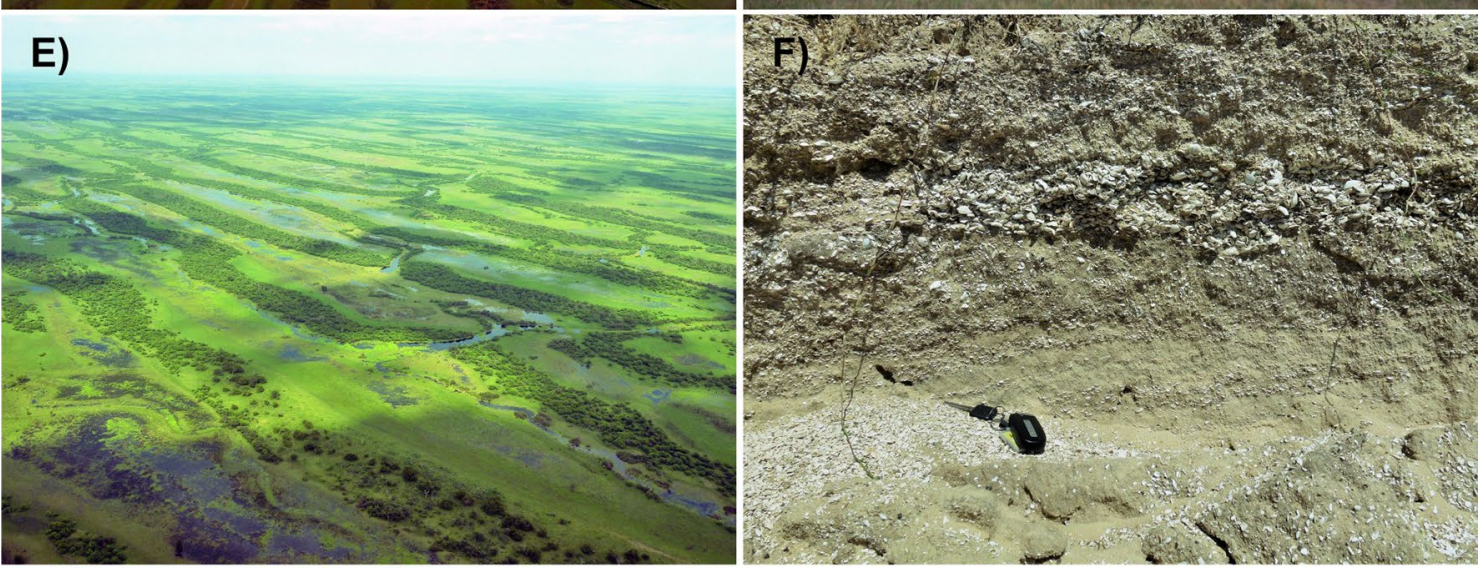

G)

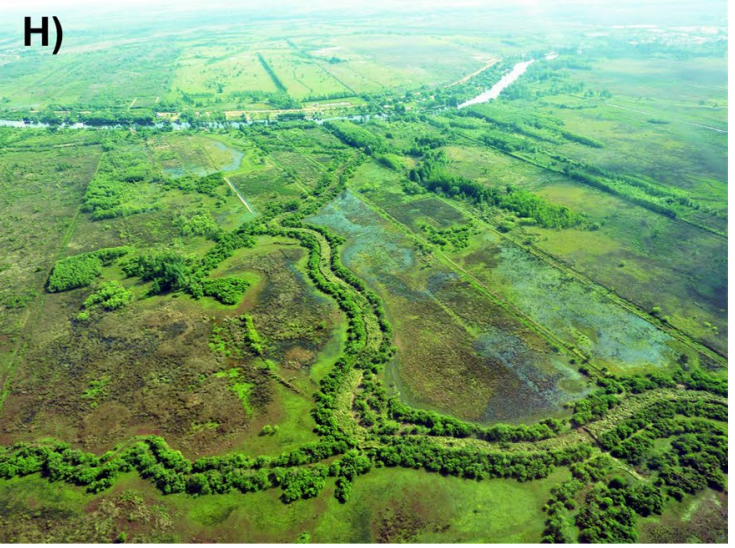


4Fig. 7 A MBEC displayed at low elevation. The area with sandy materials, where the artificial forest is located, corresponds to overwash fans. Note the small channels placed in the OCOL. The ABR sets are in the foreground. Near the Médanos village. The motorway is $30 \mathrm{~m}$ wide. B Distribution of the sandy materials of former overwash fans across the MBEC in the direction of OCOL. Westwards of Ceibas village. The motorway is $30 \mathrm{~m}$ wide. $\mathbf{C}$ The ABR sets are enhanced by their asymptotic distribution with respect to the MBEC situated on the left. Southwards of Médanos village. The straight path corresponds to the railway line ( $10 \mathrm{~m}$ wide). D ABR sets near Ceibas village. The small topographic irregularities are evidenced by the variations in the height of the wire fence $(1.5 \mathrm{~m})$. E Discontinuous chenier lineations enhanced by vegetation (Tala trees). Note their parallel distribution. Sector Q. The channel in the foreground is about $20 \mathrm{~m}$ wide. F Cross bedding evidenced by shell lineations (Erodona mactroides). Outcrop in the surroundings of Estancia La Calera (Gualeguay). Sector M. Car key for scale. G The Ibicuy Delta (ID) displays a sharp contact with the tidal flats. Note the aeolian dune field (Upper right) crossed by the railway line. Sector T. The rightangle dirt road is $10 \mathrm{~m}$ wide. H Low elevation view of former dendritic tidal channel evidenced by its vegetated levées. Far east of the sector T. The Paranacito River is in the foreground

in a framework of minor spits are displayed and other spits controlled the distribution of ABR sets in the direction of the sea-level fall (Fig. 9D). In a context with no significant sea-level variations, the generation of MBEC 10 seems to have been controlled by the development of the Gualeguay River Delta (GD), which suggests a random increase in precipitation in the Gualeguay River drainage basin because of the exceptional ENSO activity akin to that of the Super ENSO (Whang \& Ren, 2017). The correlation between the ENSO effects and the development of the main IRPE geoforms is therefore indirect (Camilloni \& Barros, 2003; Mackey, 2007; Mauas et al., 2011; Tedeschi \& Collins, 2016; Isla \& Toldo, 2013). The ENSO variations (Andreoli \& Kayano, 2005) exerted a strong influence on the weather that controlled the final configuration of the geoforms, which constitute the sedimentary infill of the IRPE. There is a random distribution of articulated whale carcasses (Eubalena australis) in some sectors where the ABR are prevalent. It does not seem reasonable to suppose that a whales could move freely because they need a minimum of water depth (more than $10 \mathrm{~m}$ ) to swim. It is highly likely that whale carcasses were dragged by strong winds (sudestadas) towards the NNW. The facies and facies associations of the ABR strandplain suggest that these probably originated in shallow water because of wind and waves (Fig. 10E). Thus, they were generated in a way like that of the beach ridges in the Brazos River (Rodríguez et al., 2000) or to the evolution of the chenier plain at San Sebastián Bay, Tierra del Fuego (Isla \& Bujalesky, 2000). In the IRPE the number of ABR sets (about 220) is consistent with the number of sets in other areas of South America or along the coast of Argentina. Nevertheless, some authors (Milana \& Kröhling, 2015) propose about 343 ABR sets in the IRPE. These studies, however, are at odds with our data and with those of other authors because of the inclusion of cheniers and chenier lineations in the total number of ABR sets (abr). At Estancia Nueva Totora (eastwards of sector $\mathrm{O}$, near Médanos village) dating of a number (25-30 $\mathrm{ABR}$ ) revealed that their growth rate varied from 0.33 $\mathrm{abr}_{\text {year }}{ }^{-1}$ to $3 \mathrm{abr}_{\text {year }}{ }^{-1}$, yielding the following values: 0.27 abr year $^{-1}, 0.62$ abr year $^{-1}$ and $2.5 \mathrm{abr} \mathrm{year}^{-1}$. Therefore, if the growth rate had been maintained along the generation of the ABR, a set of $220 \mathrm{ABR}$ would have been generated during a maximum of 778 years (year), a minimum of 84 years and a mean of 339 years.

4. The main processes that contributed to the generation of beach-ridge plains are: swash-built, setting lag, aeolian activity and storm surges (Tanner, 1995). However, the combined effect of these processes resulted in sets of parallel ridges (Fig. 10F). These sets are limited by thin discontinuities marked by small spits with an orientation that differed considerably from that of the other attached sets. The origin of these discontinuities can be attributed to energy differences, wave-orientation variations, storms, and changes in sediment-availability (Fig. 10G). The elevation of these ridges is therefore instrumental in determining whether they resulted from wave action or from aeolian activity. Note that the ridges in the lowlying areas of the Paraná coastal plain were generated by wave action. By contrast, the ridges associated with a higher elevation (Ibicuy area, ID) resulted from wind action. Hence, the beach-ridge plain of the IRPE cannot be exclusively attributed to wind variation as suggested by other authors (Milana \& Kröhling, 2015). The socalled "Pampean Sand Sea" was due to westerlies (Pamperos), whereas the orientation of the ridges between Gualeguay and Victoria strongly suggests wave effects due to sudestadas during the Mid-Holocene highstand. This occurred in the former embayment prior to the regression of the Río de la Plata in the Late-Holocene.

5. Given that the MBEC is about $300 \mathrm{~km}$ long, about $600 \mathrm{~m}$ wide and $6 \mathrm{~m}$ high, it is possible to calculate its total volume, i.e., the exposed lithosome of the MBEC is $180 \times 10^{6} \mathrm{~m}^{3}$, which is equivalent to $288 \times 10^{6} \mathrm{t}$ (metric tons). The present load of the Paraná River is $90 \times 10^{6}$ tons/year $\left(\mathrm{t}\right.$ year ${ }^{-1}$ ) and that of the Uruguay River is $10 \times 10^{6} \mathrm{t}_{\text {year }}{ }^{-1}$. The load of the PUR system is $100 \times 10^{6} \mathrm{t}^{\text {year }}{ }^{-1}$, which is equivalent to $62.5 \times 10^{6}$ $\mathrm{m}^{3} \mathrm{year}^{-1}$. The times calculated for the generation of MBEC vary as a function of selected formulae (Table 3). Thus, when the Engelund and Hansen (1966) formula (Vanoni, 1975) is applied $\left(\mathrm{Q}=15 \times 10^{6} \mathrm{t} \mathrm{year}^{-1}\right)$ and when the total retention is $100 \%$, the time calculated is 19.2 years. When the retention is $40 \%$, the time reached is 48 years. When the retention is $20 \%$, the time attained 
Fig. 8 Schematic dynamics of the sequential infill of the IRPE during the mid-Holocene. Compare with Fig. 3. Several events (A, B) may be distinguished. A Stage of the IRPE during the mid-Holocene maximum flooding stillstand and the approximate location of the Paraná River. Present locations of main towns are displayed.

B Early and episodic development (1-3) of the main coastal estuarine barrier (MBEC) which controlled the development of the large lagoon (OCOL). This lagoon displays the distribution of tidal channels and overwash fans that were generated by recurrent high-energy storms

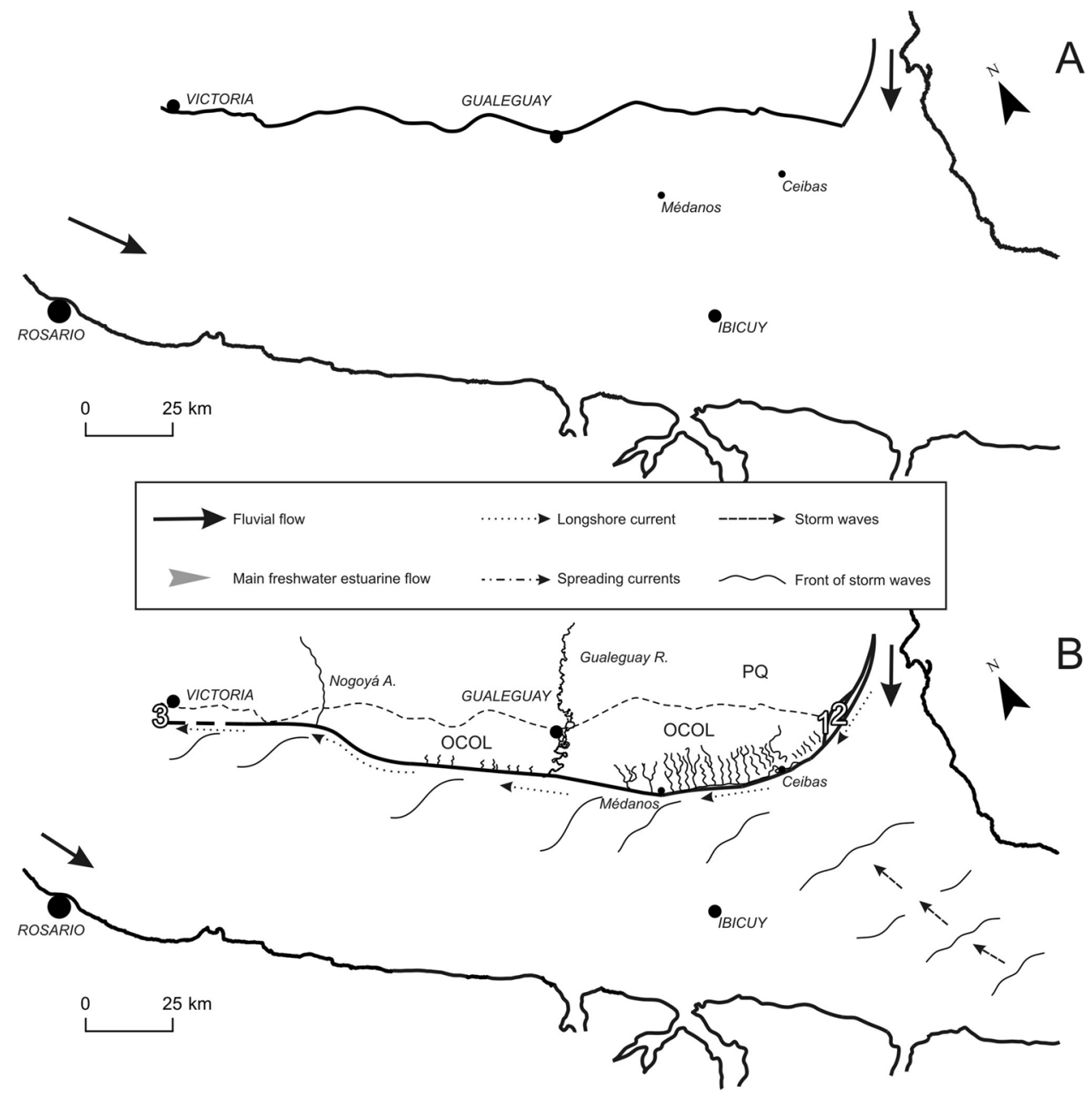

is 96 years. However, if the Orfeo (1995) formula is applied $\left(\mathrm{Q}=24 \times 10^{6} \mathrm{t} \mathrm{year}^{-1}\right)$ and if the total retention is $100 \%$, the time calculated is 12 years. If the retention is $40 \%$, the time attained is 30 years, whereas if the retention is $20 \%$, the time reached is 60 years. These calculations suggest that the MBEC developed rapidly within a relatively short time span. Based on the proposed formulae, our results show that the growth rate of MBEC is relatively rapid. However, it is not easy to accept that the growth rate is fast without considering that the materials constituting MBEC could have been partially or extensively reworked from former sedimentary accumulations.

6. The formulae consider present hydrological parameters of the PUR system, but evidence for these parameters in geological times is not easy to substantiate. The natural variation of the PUR system is characterized by large floods and severe droughts along historical times. The present hydrological parameters of large floods employed in the theoretical calculations of the sediments (mud and sands) for the growth of the MBEC cannot therefore be used. Extraordinary floods that carry very large supplies of solid load imply that the MBEC generation could be produced at high velocity. Note that the PUR system underwent severe droughts in the XVIII Century during which fluvial navigation (from Buenos Aires to Asunción) along the Paraná River was suspended. Trade, however, was resumed by land on the right bank of the river. Prolonged periods of drought would considerably reduce the sediment supply, leading to a significant increase in the time necessary for the growth of the MBEC. By contrast, extended rainfall periods during which reworked materials mixed with the usual load supplied by the PUR system would reduce the time needed for the generation of the MBEC. At the present time, however, convincing evidence for this scenario is not available.

7. It should be pointed out, however, that the MBEC developed along the left bank of the IRPE from the SSE to NNW during the sea-level rise (Fig. 11). The MBEC boundaries were probably due to the run-up effects of the sudestadas. This process may account for the similar data obtained along the MBEC though not in the areas affected by lateral tributaries such as the Nogoyá Arroyo 
Fig. 9 Continuation of sequential infill $(\mathbf{C}, \mathbf{D})$ of the IRPE during the mid-Holocene. Compare with Fig. 3. C The Nogoyá Arroyo Delta (ND) development controlled the westwards displacement of MBEC producing a new barrier (4). D The Gualeguay River Delta (GD) controlled the westwards displacement of the MBEC resulting in a new barrier that was also affected by outwash fans. The new MBEC (10) generated other sets of $\operatorname{ABR}(8,9)$
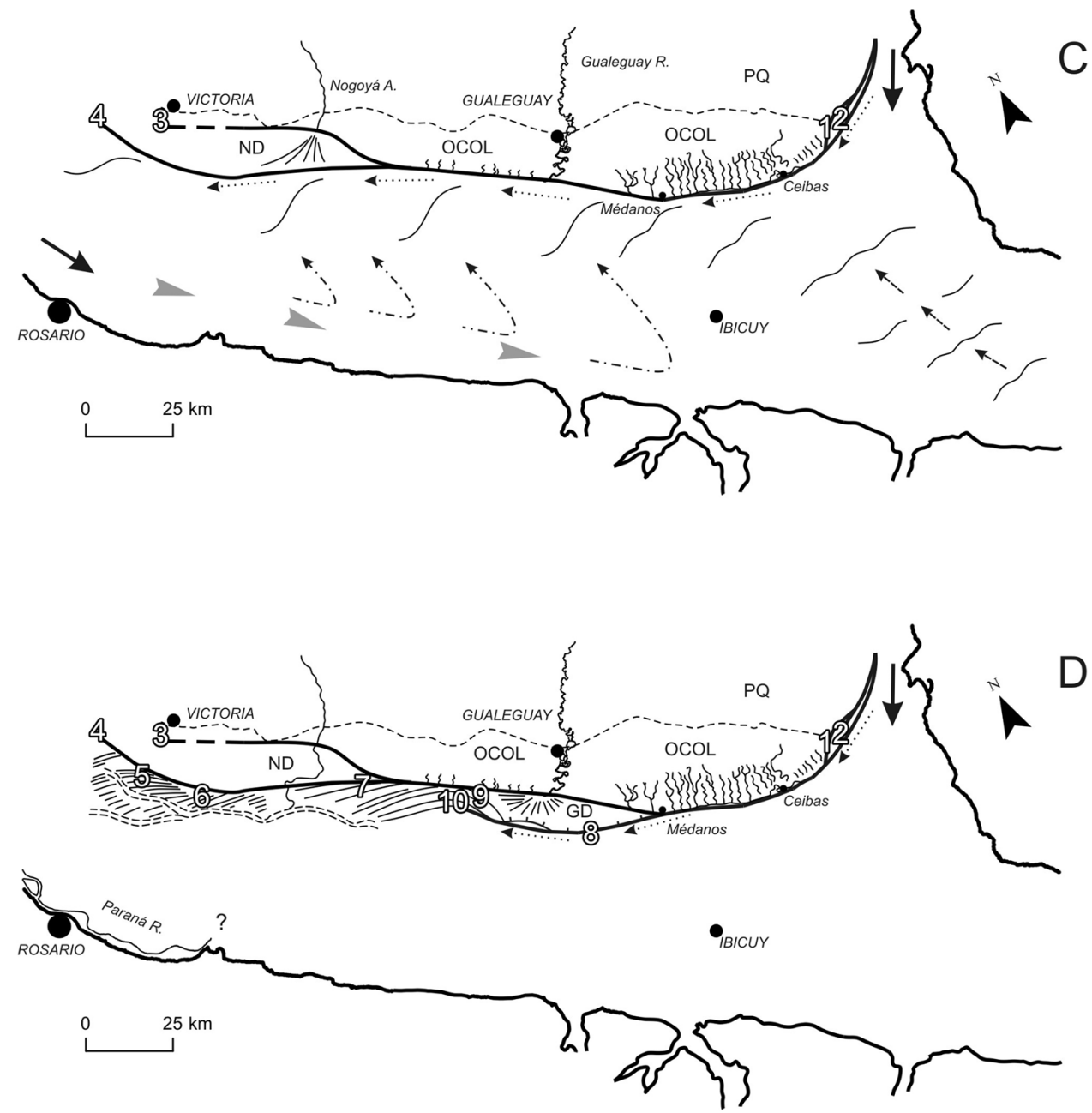

and the Gualeguay River. The sedimentary inputs from these fluvial courses probably supplied very recent sediments (about 4000 years BP) to the intermediate sector of the MBEC, whereas the average chronology is about 6000 years BP in the downstream and upstream sectors. The eustatic maximum was attained when the Rio de la Plata Estuary (about $630 \mathrm{~km}$ ) underwent flooding from the "Barra del Indio" to Diamante (Figs. 2, 3). This maximum probably occurred at a mean elevation rate of about $0.23-0.50 \mathrm{~cm}_{\text {year }}{ }^{-1}$. The main flooding (equivalent to $81 \times 10^{10} \mathrm{~m}^{3}$ year $^{-1}$ ) was rapid (about 3000 years) and resulted in an extensive remobilization of an earlier accumulation of sediments from the former PUR system. This led to the MBEC, which grew coevally with the rise in sea-level.

8. Dating of shells $\left({ }^{14} \mathrm{C}\right)$ yields some ages that are inconsistent with those obtained from the OSL procedures. These anomalies are probably due to the reservoir effects on the dates because of a mixing of fresh, salt, and brackish waters (Heier-Nielsen et al., 1995; Stuiver
\& Braziunas, 1993; Ulm, 2000, Blackwell et al., 2004), which stunted the growth of shells in the former Río de la Plata Estuary. Radiocarbon dating errors are not uncommon given that the reservoir effects in estuaries are more complex than in marine or continental environments owing to different water dynamics, climate, and geomorphological characteristics (Hughen et al., 2004; McCormac et al., 2004). It should be noted that radiocarbon is directly added into the living organisms that are in equilibrium with the atmosphere and with fresh, brackish, or marine waters. However, radiocarbon can be indirectly incorporated into other organisms (calcite/ aragonite) from different areas because of post depositional processes (diagenetic). This yields a diversity of reservoir effects on radiocarbon dating of estuarine samples (Phillippsen, 2013). The increase in the supply of carbonated waters could also be attributed to the washing effects of carbonate-rich loess (Teruggi, 1957) in the province of Entre Ríos. 

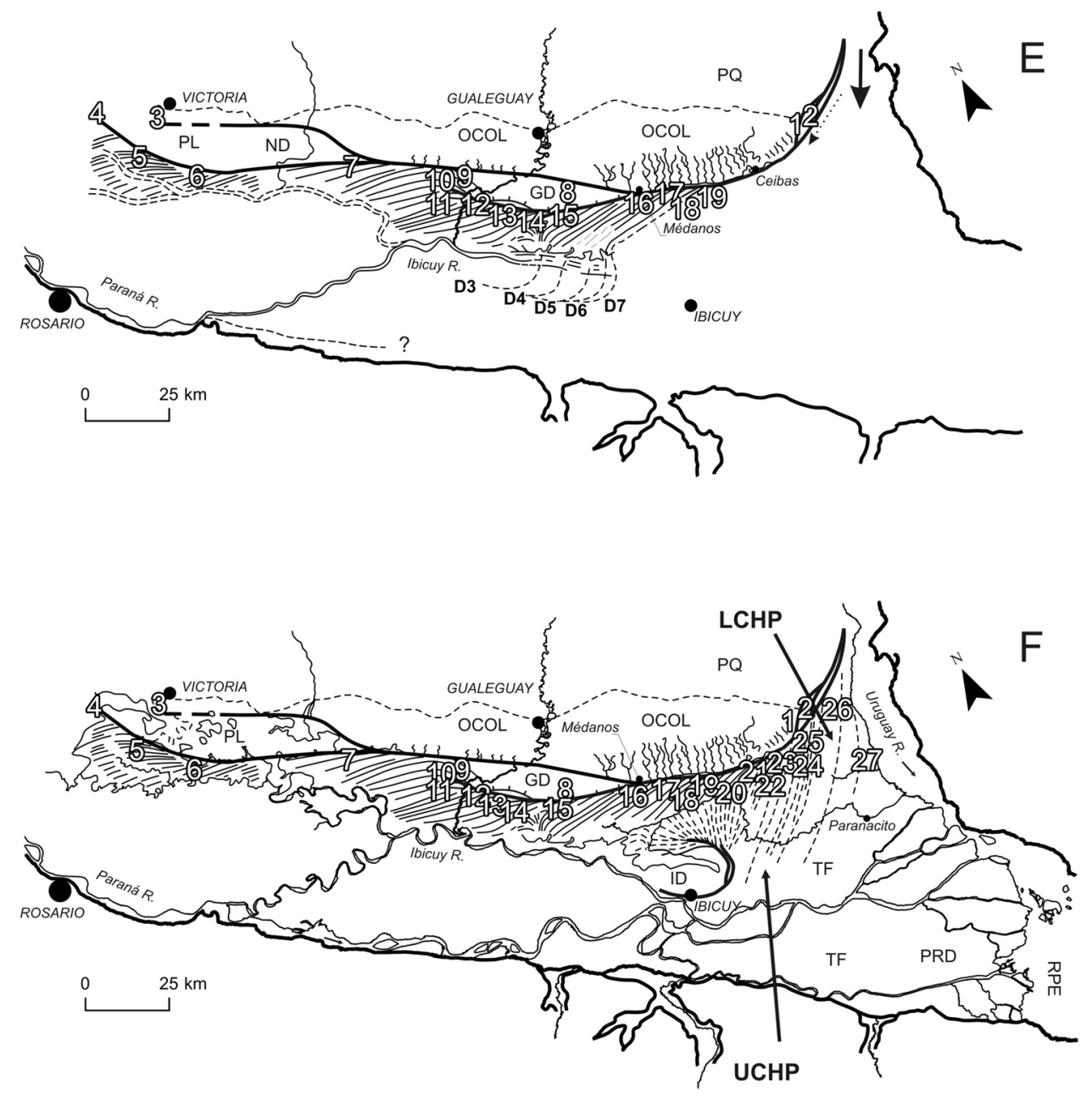

Fig. 10 Sequential infill of the IRPE during the mid-Holocene. Compare with Fig. 3. Several events (E, F) may be distinguished. E The generation of new sets (11-14) of ABR continued during the displacement of the Paraná River to the right bank of the IRPE. The subsequent course of the Paraná River resulted in the reworking of sandy materials in the early ABR sets. and in the initial accumulation of deltaic bodies $\left(D_{1}-D_{7}\right)$ of Ibicuy (ID). The generation of new sets (15-19) of ABR continued during the displacement of the Paraná River to the left bank of the IRPE. F The sedimentary infill continued during the last episodes of stillstand that led to the generation of ID, which was coeval with the development of several cheniers (20-23). Subsequently, the southwards avulsion of the former Ibicuy River produced the abandonment of the ID. Thereafter, a chenier strandplain developed coevally with other bars (24-26). A new stage corresponds to the development of tidal flats (TF), which are displayed as Upper Chenier Plain (UCHP) and Lower Chenier Plain (LCHP), respectively. Finally, the last chenier (27) and the present-day Paraná Delta (PRD)

\section{Schematic evolution}

Given that all the sedimentary environments developed coevally and that their facies were genetically related, the sedimentary infill of the IRPE (Table 4) corresponds to a depositional system that was active along the Holocene (Colombo et al., 2014a). Accordingly, the stages of the evolution of the sedimentary infill of the IRPE are as follows:

1. The morphology of the sedimentary basin was controlled by the activity of the PUR system in pre-Holocene times. Inherited bedforms have been identified in the valley and assigned to the last interglacial

highstand (Isla \& Madirolas, 2009). Thus, along the last glacial maximum (LGM) in a context of a marine regression, the paleovalley was displaced to the right bank of the IRPE (Iriondo, 2010), triggering erosion that controlled its linear morphology. During the midHolocene (Fig. 8A), the marine transgression caused extensive flooding which led to the formation of the Río de la Plata Estuary (RPE), and to a gradual aggradation of the levee on its left bank (7400-6800 years $\mathrm{BP})$., which contributed to the MBEC. The generation and adjustment of the MBEC occurred during and after the last highstand (about 6000 years BP) when the maximum flooding surface reached about 5-6 
Table 3 Schematic calculation for the MBEC generation due to retention of sediments carried by the fluvial system and the time needed

\section{Total retention}

Load transport

(a) $\emptyset>15 \mu \mathrm{m}$

(b) $\varnothing>63 \mu \mathrm{m}$

(a) Engelund \& Hansen equation

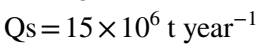

Time needed for MBEC generation $288 \times 10^{6} \mathrm{~m}^{3}$

b) Orfeo equation

Qs $=24 \times 10^{6} \mathrm{t} \mathrm{year}^{-1}$

Time needed for MBEC generation $288 \times 10^{6} \mathrm{~m}^{3}$
$10 \%$

$20 \% \quad 40 \% \quad 60 \% \quad 80 \% \quad 100 \%$

The MBEC total volume is about $180 \times 10^{6} \mathrm{~m}^{3}$, which is equivalent to $288 \times 10^{6} \mathrm{t}$ (metric tons). The total load transported by the Paraná-Uruguay River system (PUR) is about $62.5 \times 10^{6} \mathrm{~m}^{3}$ year $^{-1}$, which is equivalent to $100 \times 10^{6} \mathrm{t}_{\text {year }}^{-1}$ with a mean density of sediments of about $1.6 \mathrm{t} / \mathrm{m}^{3}$. The calculated (b) bed load $(\hat{\varnothing}>63 \mu \mathrm{m})$ is $15 \times 10^{6} \mathrm{t}^{\text {year }}{ }^{-1}$ applying the Engelund and Hansen (1966) equation (Vanoni, 1974). Moreover, the calculated (a) bed load $(\hat{\varnothing}>15 \mu \mathrm{m})$ applying the Orfeo (1995) equation is $24 \times 10^{6} \mathrm{t} \mathrm{year}^{-1}$. The retention values of the $10 \%, 20 \%, 40 \%, 60 \%, 84 \%$ and $100 \%$ for the direct generation of the MBEC are considered for comparison with the results of the equations applied

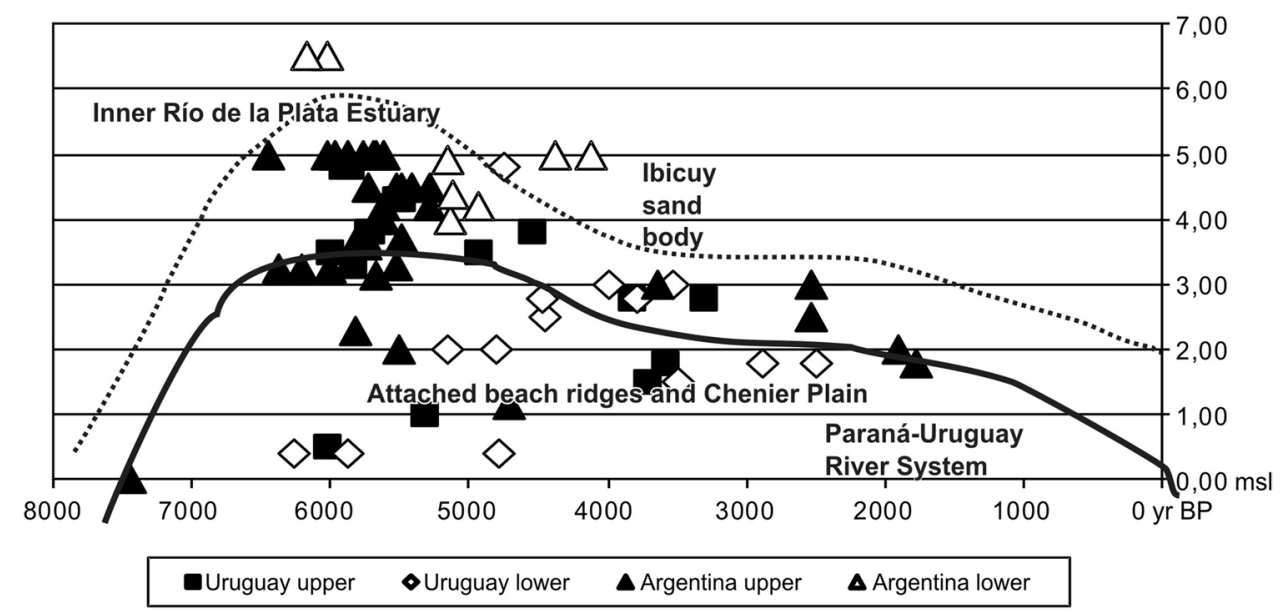

Fig. 11 Sea-level variations of the Río de la Plata Estuary that are distinguished from the mean sea-level (solid line) and the meteorological effects of southeastern storms (dotted line). These data concern both banks of the Río de la Plata (Argentinian and Uruguayan), and their upper and lower reaches. The Argentina upper and Argentina lower correspond to upstream and downstream of the Paraná River, respectively. The Uruguay upper and Uruguay lower correspond to upstream and downstream of the Uruguay River, respec-

msl. The MBEC developed in stages as evidenced by the growth of the first and second bars ( 1 and 2 in Fig. 8B) along the right bank of the Uruguay River. Thereafter, the MBEC, which continued prograding northwards, reached the proximity of Victoria. The OCOL came into existence between the MBEC and the pre-Holocene basement of the province of Entre Ríos. The presence of tidal channels, which crossed the MBEC and penetrated the OCOL, suggests that several outwash fans affected the MBEC because of recurrent high-energy storms (Fig. 3). tively. Beaches resulting from the maximum highstand developed in the Inner Río de la Plata Estuary (IRPE). During the regression, beach ridges and chenier systems extended across the Province of Entre Ríos. The Ibicuy sand body is the Ibicuy Delta (ID, Fig. 3) that was reworked by waves and winds during the southeasterlies (sudestadas). Data from other publications (Cavallotto et al., 2004, 2005; Codignotto et al., 1992; Colombo et al., 2014a; Guida \& González, 1984, and references herein)

2. The sedimentary activity of the Nogoyá Arroyo and the Gualeguay River played a crucial role in the development of the OCOL, which gave rise to two areas separated by the Gualeguay River. The predominant sandy materials of the MBEC resulted from earlier IRPE accumulations that were reworked. These materials were supplied by the sedimentary activity of the PUR system during the transgression. In the IRPE, the counterclockwise water circulation was controlled by strong waves and winds from SE (sudestadas), which transported sediments supplied by longshore currents 
Table 4 Schematic evolution of the IRPE sedimentary infill

\begin{tabular}{llllll}
\hline 1 Time y BP & 2 Time y BP & Geoforms & Sea-level & Meteor & Evolution \\
\hline & \multirow{2}{*}{$695-410$} & A. Dunes/LCHP & Gradual Fall & & 9 \\
1770-1690 & & LCHP/A. Dunes & Gradual Fall & & 8 \\
$2500-1900$ & & UCHP/ABR & Gradual fall/Sb & & 7 \\
$3400-2800$ & & ID D. Frt./UCHP & Sb./Gradual fall & ENSO event IV? & 6 \\
& \multirow{2}{*}{$3600-2100$} & ABR/ID D. Frt & Stabilization & & \\
& $4750-4400$ & MBEC/ABR/ID & Stabilization & ENSO event III & 5 \\
$4700-2500$ & & MBEC/ABR & Gradual Fall & & 4 \\
$5500-5300$ & & MBEC/OCOL/GD & Stillstand & ENSO event II & 3 \\
& \multirow{2}{*}{$6900-5600$} & MBEC/ABR/ND & Stillstand & ENSO event I & 2 \\
$7400-6800$ & & MBEC/PL & Highstand & & 1
\end{tabular}

1 Time y BP show the wide time lapses; 2 Time y BP displays the detailed time lapses; Geoforms are related to the main geoforms studied (Compare with Fig. 3); A. Dunes aeolian dunes, ID Ibicuy Delta, $D$. Frt. delta front, Sea-level are the variations in sea-level, Sb. Stabilization, Meteor, hows the main meteorological episodes related to the ENSO events, Evolution refers to the proposed main steps of evolution. towards the N and NNW along the left bank of the IRPE. This supply triggered the gradual growth of the MBEC along the right bank of the Uruguay River as far as Victoria (about $300 \mathrm{~km}$ ) upstream of the Paraná River (3 in Fig. 8B). The MBEC developed in the midHolocene of the final transgression that was marked by a prominent highstand. The sedimentary activity of Nogoyá Arroyo produced a delta (ND) probably because of the ENSO (ENSO event I, Table 4) during the Holocene (6900-5600 years BP). The southwestwards expansion of ND altered the former course of NNW longshore currents, leading to the generation of a new barrier (4 in Fig. 9C) during the mid-Holocene. Subsequently, the fluvial dynamics controlled the partial flooding of the area that is at present covered by a permanent lagoon (PL), masking the main geoforms. The ND crops out only in the SE sector of the PL, which constitutes its southern boundary.

3. There are numerous NNW oriented small bars (numbered spits) associated with the southern boundary of the MBEC. These bars were generated by the predominant longshore currents during subtle variations of sea-level in the innermost sector of the RPE $(5,6$, 7, 8 and 9 in Fig. 9D). Another barrier of the MBEC developed from the sedimentary activity of the Gualeguay River (ENSO event II, Table 4). This produced a small delta (GD) which displaced the NNW course of the main longshore currents (5500-5300 years BP). Other small NNW directed bars were associated with the new MBEC, which resulted from the coalescence (amalgamation) of smaller bars. This suggests subtle variations in sea-level during the sand supply owing to predominant and continuous longshore currents. The associated sets of beach ridges (ABR) developed coevally.
4. The small spits (bars) constitute the boundaries of different sets of ABR attached to the MBEC (4700-2500 years BP). These bars were produced by the accumulation of sands carried by longshore currents during a short stillstand event. The variations of the ABR sets reflect the stillstand duration. However, the chronological data shed little light on the duration of each episode.

5. A new distributary of the Paraná River along the left margin of the IRPE gave rise to the former Ibicuy River. This distributary controlled the levées (47504400 years BP) and the former deltas $\left(D_{1}-D_{7}\right.$ in Fig. 10E) owing to the large amount of sand in the area (ENSO event III, Table 4). The geometrical distortion of several ABR (bars 15-20) reflects the coeval growth of these small deltas (3600-2100 years BP).

6. The development of the ID, which has been attributed to an ENSO-triggered flood (Depetris et al., 1996; Kanner et al., 2013; Pasquini \& Depetris, 2010), strongly suggests a mid-Holocene (3400-2800 years BP) stillstand stabilization (probably ENSO event IV, Table 4). that also led to the coeval growth of several cheniers eastwards of the ID. These were connected to the main MBEC in the proximity of Ceibas (bars 21-22).

7. The chenier lineations were linked to the ID deltaic front bars that were exposed to strong sudestadas. The upper chenier plain (UCHP), which shows few outcrops (cheniers 23-25) towards the ESE of the ID, highlights a large supply of sand and a small supply of mud. In contrast, the lower chenier plain (LCHP) displays a large supply of mud and a small supply sand along the right bank (cheniers 26-27) of the Uruguay River (Fig. 10F). Some old cheniers (UCHP) are dated at 2500-1900 years BP. 
8. Some cheniers (UCHP) are dated at about $1770-1690$ years BP.

9. The more recent dunes are dated at about $695-533$ years BP. Whereas the more recent cheniers (LCHP) are dated at about 410 years BP, reflecting the marked decrease in the progradation rates of the IRPE

10. The significant variations in sedimentation and the sealevel stabilization (Fig. 11) contributed to the rapid development of the present Paraná Delta towards the SE, attaining a mean rate of about 25-70 $\mathrm{m}_{\text {year }}{ }^{-1}$ (Sarubbi et al., 2004).

\section{Conclusions}

1. New chronological data together with the genetic interpretation of the main sedimentary geoforms yield fresh insight into the sedimentary dynamics of the IRPE. Although the data from OSL analysis underwent variations in the analytical procedures, they are in line with the development of the main sedimentary forms in the IRPE.

2. The MBEC was due to the gradual marine highstand. This coincided with the maximum flooding surface that occurred approximately 6000 years BP in southern Brazil and in the IRPE. The MBEC was generated by longshore currents and waves that transported many sediments upstream along the palaeo-estuary within a relatively short time span. The ages are therefore similar along the MBEC and were affected by some local rejuvenation due to overwash and high energy thunderstorms.

3. The small variations in elevation between the MBEC 3 and MBEC 4 suggest that these geoforms were not controlled by fluctuations in sea-level. Thus, the displacement of the MBEC from position 3 to 4 was the result of the growth and progradation of the Nogoyá Arroyo Delta (ND), which produced a significant variation in the IRPE palaeogeography and, hence, in the local dynamics of longshore currents.

4. The development of the main geoforms of the IRPE may be attributed to several factors: variations in the discharge of the PUR system, changes in the sediment load, intense winds (sudestadas), variations in the relative sea-level, climate change due to solar cycles and to the varying periodicity and intensity of ENSO.

5. The displacement of the MBEC from position 4 to 10 was controlled by another intense ENSO season during which the growth and progradation of the Gualeguay River Delta (GD) led to the displacement of the MBEC. Thus, the ENSO, which was randomly distributed over the area, played a part in the shift of the MBEC positions about $300 \mathrm{~km}$ along the left bank of the IRPE.

6. The frequency of the ENSO results in a great variability in its activity between 6000 years BP and 3000 years BP. Its recent and rapid recurrence exerts a strong influence over sedimentary activity in the IRPE. The beach-ridge plain of the IRPE, which is reconstructed from a combined data set of Radiocarbon and OSL dates, is therefore -spatially and temporally- like those other coastal plains of South America.

7. A long-term fall in sea-level had a profound impact on the evolution of the IRPE during the Late-Holocene and on the development of small deltas such as those of Nogoyá, Gualeguay and Ibicuy rivers. Along the Holocene, the ENSO effects played a major role in supplying variable amounts of suspended sediments to the PUR system. Wave and storm effects were also instrumental in establishing depositional gaps between the ABR episodic processes and in contributing to the longshore growth of estuarine spits in a progradational trend.

8. The sea-level gradually fell to the present level at an average rate of about $1 \mathrm{~mm}$ year $^{-1}$. The small variations in the intermediate sea-level positions contributed to the growth of minor spits along the southern bank of the MBEC. Moreover, the generation of ABR was also influenced by subtle variations in sea-level. This occurred coevally with successive spits that constituted the local framework of many ABR sets.

9. 9.- It is worth noting that two samples from the Médanos-Ceibas area that includes about $80-82$ beach ridges yields ages of 3590 years BP and 2495 years BP, indicating a periodicity of 13.4-13.7 years for the development of each beach ridge. Like the periodicity of the ENSO effects, these data could be associated with the variability of sunspots. At present, however, we lack compelling evidence for the role of sunspots in the recurrent PUR floods that controlled the development and general distribution of the MBEC.

Acknowledgements We are indebted to the owners and workers of the following Cattle stations for access to study the main geomorphological features within their property: Estancia El Reposo-Estancia Anchorena (Ibicuy), Estancia Don Elías (east of Ceibas village), Estancia el Palmar, Estancia Lunalinda, Estancia la Natividad and Estancia La Tola (Médanos area), Estancia El Potrillo, Estancia Nueva Totora, Estancia La Calera, Estancia La Conchera de Flores (Gualeguay area) and Estancia la Azotea (Ceibas area). The work was supported by the GCL2012-38396-C03-03 project of the Spanish Program for Science and Technology and was partially funded by the Generalitat de Catalunya (Grup de Qualitat 2014- SGR-467. The comments of P. Busquets, M. López-Blanco, E. Anthony, N. Heredia and two anonymous referees have considerably improved the earlier versions of the manuscript.

Funding Open Access funding provided thanks to the CRUE-CSIC agreement with Springer Nature. 
Open Access This article is licensed under a Creative Commons Attribution 4.0 International License, which permits use, sharing, adaptation, distribution and reproduction in any medium or format, as long as you give appropriate credit to the original author(s) and the source, provide a link to the Creative Commons licence, and indicate if changes were made. The images or other third party material in this article are included in the article's Creative Commons licence, unless indicated otherwise in a credit line to the material. If material is not included in the article's Creative Commons licence and your intended use is not permitted by statutory regulation or exceeds the permitted use, you will need to obtain permission directly from the copyright holder. To view a copy of this licence, visit http://creativecommons.org/licenses/by/4.0/.

\section{References}

Albero, M. C., \& Angiolini, F. E. (1983). INGEIS radiocarbon laboratory dates I. Radiocarbon, 25, 831-842.

Amato, S., \& Silva Busso, A. (2009). Estratigrafía cuaternaria del subsuelo de la cuenca inferior del río Paraná. Revista De La Asociación Geológica Argentina, 64, 594-602.

Andreoli, R. V., \& Kayano, M. T. (2005). ENSO-related rainfall anomalies in South America, associated circulation features during warm and cold Pacific decadal oscillation regimes. International Journal of Climatology, 25, 2017-2030.

Antico, A., Torres, M. E., \& Diaz, H. F. (2016). Contributions of different time scales to extreme Paraná floods. Climate Dynamics, 46, 3785-3792.

Augustinus, P. G. E. F. (1989). Cheniers and chenier plains: A general introduction. Marine Geology, 90, 219-229.

Bateman, M. D. (Ed.). (2019). Handbook of luminescence dating (pp. 1-400). Whittles Publishing.

Bischoff, S. (2006). Sudestadas. In: V. R., Barros, A., Menéndez, \& G. Nagy (Eds.), El Cambio Climático en el Río de la Plata. UBA-CONICET, Buenos Aires, p. 53-68.

Blackwell, P. G., Buck, C. E., Burr, G. S., Cutler, K. B., Edwards, R. L., Fairbanks, R. G., Friedrich, R. G. M., Guilderson, T. P., Kromer, B., McCormac, G., Manning, S., Ramsey, C. B., Reimer, P. J., Reimer, R. W., Remmele, S., Southon, J. R., Stuiver, M., Talamo, S., Taylor, F. W., ... Weyhenmeyer, C. E. (2004). Marine04 marine radiocarbon age calibration, 0-26 cal ky BP. Radiocarbon, 46, 1059-1086.

Brunetto, E., Ferrero, B. S., \& Noriega, J. I. (2015). Late Pleistocene lithostratigraphy and sequences in the southwestern Mesopotamia (Argentina): Evidence of the last interglacial stage. Journal of South American Earth Sciences, 58, 111-128.

Camilloni, I. A., \& Barros, V. R. (2003). Extreme discharge events in the Paraná River and their climate forcing. Journal of Hydrology, 278, 94-106.

Cavallotto, J. L., Bonomo, N., Grunhut, V., Zabala Medina, P., Violante, R. A., Onnis, L., \& Osella, A. (2020). Shallow geophysical methods for recognition of Holocene sedimentary sequences in the southern coastal plain of the Río de la Plata (Argentina). Journal of South American Earth Sciences. https://doi.org/10. 1016/j.jsames.2020.102662

Cavallotto, J. L., Violante, R. A., \& Colombo, F. (2005). Evolución y cambios ambientales de la llanura costera de la cabecera del Río de la Plata. Revista De La Asociación Geológica Argentina, 60, 353-367.

Cavallotto, J. L., Violante, R. A., \& Parker, G. (2004). Sea-level fluctuations during the last 8,600 years in the de la Plata River (Argentina). Quaternary International, 114, 155-165.

Cazes-Boezio, G., Robertson, A. W., \& Mechoso, C. R. (2003). Seasonal Dependence of ENSO Teleconnections over South
America and Relationships with the Precipitation in Uruguay. Journal of Climate, 16, 1159-1176.

Cellone, F., Carol, E., \& Tosi, L. (2016). Coastal erosion and loss of wetlands in the middle Río de la Plata estuary (Argentina). Applied Geography, 76, 37-48. https://doi.org/10.1016/j. apgeog.2016.09.014

Codignotto, J. O., \& Aguirre, M. K. (1993). Coastal evolution in sea level and molluscan fauna in northeastern Argentina during the Late Quaternary. Marine Geology, 110, 163-175.

Codignotto, J. O., Dragani, W. C., Martin, P. B., Campos, M. I., Alonso, G., Simionatto, C. G., \& Medina, R. A. (2011). Erosión en la bahía de Samborombón y cambios en la dirección de los vientos, provincia de Buenos Aires, Argentina. Revista Museo Argentino De Ciencias Naturales, N.s., 13(2), 135-138.

Codignotto, J. O., Kokot, R. R., \& Marcomini, S. C. (1992). Neotectonism and Sea-Level Changes in the Coastal Zone of Argentina. Journal of Coastal Research, 8, 125-133.

Colombo, F., Rivero, L., \& Casas, A. (2007). Contribución del Georadar a la estratigrafía del Delta del Río Paraná (Argentina): Primeros resultados. Geogaceta, 41, 55-58.

Colombo, F., Serra, J., \& Rivero, L. (2014a). Río de la Plata Inner Estuary (Argentina): Main Forms, sedimentary infill and Holocene Evolution. Geological Society of London. Special Publication, 388, 305-331.

Colombo, F., Serra, J., Bedmar, J., \& Isla, F. I. (2014b). Holocene infill of the innermost sector of the Río de la Plata Estuary (Argentina). In: XIX Congreso Geológico Argentino. Córdoba, T. 9-3.

Colombo, F., Violante, R., Cavallotto, J. L., \& Parker, G. (2000). Caracterización morfosedimentaria de la llanura costera entre el Río Paraná Guazú y las localidades de Ibicuy y Gualeguay, Entre Ríos, Argentina. Geogaceta, 28, 31-34.

Dalla Salda, L. (1999). Cratón del Río de la Plata. In. (Caminos, R., Ed.). Geología Argentina. Instituto de Geología y Recursos Minerales. Servicio Geológico Minero Argentino, Anales 29 (4), 97-106.

Dalla Salda, L., Bossi, J., \& Cingolani, C. (1988). The Rio de la Plata cratonic región of southwestern Gondwana. Episodes, 11, 263-269.

Del Rio, C. J., Martínez, S. A., McArthur, J. M., Thirlwall, M. F., \& Pérez, L. M. (2018). Dating late Miocene marine incursions across Argentina and Uruguay with Sr-isotope stratigraphy. Journal of South American Earth Sciences, 85, 312-324.

Depetris, P. J., \& Griffin, J. J. (1968). Suspended load in the Rio de la Plata drainage basin. Sedimentology, 11, 53-60.

Depetris, P. J., Kempe, S., Latif, M., \& Mook, W. G. (1996). ENSOcontrolled flooding in the Parana River (1904-1991). Naturwissenschaften, 83, 127-129.

Engelund, F., \& Hansen, E. (1966). Investigations of flow in alluvial streams. Acta Polytechnica Scandinavica Civil Engineering and Building Construction Series, 35, 1-100.

Escobar, G. C., Vargas, W. M., \& Bischoff, S. A. (2004). Wind tides in the Río de la Plata estuary: Meteorological conditions. International Journal of Climatology, 24, 1159-1169.

Fisher, W. L., \& McGowen, J. H. (1967). Depositional systems in the Wilcox Group of Texas and their relationship to occurrence of oil and gas. Trans Gulf Coast Association of Geological Societies, $17,105-125$.

Fucks, E., Blasi, A., Carbonari, J., Huarte, R., Figini, A., Pisano, F., \& Aguirre, A. (2011). Evolución geológica-geomorfológica de la cuenca del Rio Areco, NE de la provincia de Buenos Aires. Revista De La Asociación Geológica Argentina, 68, 109-120.

García, N. O., \& Mechoso, C. R. (2005). Variability in the discharge of South American rivers and in climate. Hydrological Sciences Journal, 50, 459-477. 
Guida, N. G., \& González, M. A. (1984). Evidencias paleoestuáricas en el sudeste de Entre Ríos, su evolución con niveles marinos relativamente elevados del Pleistoceno superior y Holoceno. In: $9^{\circ}$ Congreso Geológico Argentino. Actas III, 577-594, Bariloche.

Hart, E. A., Stapor, F. W., Novoa-Jerez, J. E., \& Sutherland, C. J. (2016). Progradation of a Beach Ridge Plain between 5000- and 4000-Years BP inferred from luminescence dating, Coquimbo Bay, Chile. Journal of Coastal Research. https://doi.org/10.2112/ JCOASTRES-D-16-00052

Heier-Nielsen, S., Conradsen, K., Heinemeier, J., Knudsen, K. L., Nielsen, H. L., Rud, N., \& Sveinbjönsdóttir, A. E. (1995). Radiocarbon dating of shells and foraminífera from the Skagen core, Denmark: Evidence of reworking. Radiocarbon, 37, 119-130.

Hughen, K. A., Baillie, M. G. L., Bard, E., Beck, J. W., Bertrand, C. J. H., Blackwell, P. G., Buck, C. E., Burr, G. S., Cutler, K. B., Edwards, R. L., Fairbanks, R. G., Friedrich, R. G. M., Guilderson, T. P., Kromer, B., McCormac, G., Manning, S., Ramsey, C. B., Reimer, P. J., Reimer, R. W., ... Weyhenmeyer, C. E. (2004). Marine04 marine radiocarbon age calibration, 0-26 cal ky BP. Radiocarbon, 46, 1059-1086.

Iriondo, M. H. (2010). Las grandes llanuras. In: A. Arche (Ed.), Sedimentología: Del proceso físico a la Cuenca sedimentaria, 1251-1274. Textos Universitarios 46, Consejo Superior de Investigaciones Científicas (CSIC).

Isla, F. I. (1989). The Southern Hemisphere sea-level fluctuation. Quaternary Science Reviews, 8, 359-368.

Isla, F. I. (1998). Holocene coastal evolution of Buenos Aires. Quaternary of South America \& Antarctic Peninsula, 11, 297-321.

Isla, F. I. (2008). ENSO-dominated estuaries of Buenos Aires. The interannual transfer of water from Western to Eastern South America. Global and Planetary Change, 64, 69-75.

Isla, F. I., \& Bujalesky, G. G. (2000). Cannibalization of Holocene gravel beach-ridge plains, northern Tierra del Fuego, Argentina. Marine Geology, 170, 105-122.

Isla, F. I., \& Espinosa, M. (2021). The Gravels of the Rio De La Plata: The Holocene Beaches of the Bella Vista. Uruguay. Journal of Coastal Research. https://doi.org/10.2112/JCOAS TRES-D-20-00142.1

Isla, F. I., \& Madirolas, A. (2009). Submerged Pleistocene highstand at the Inner Shelf of the Río de la Plata. The assymetry of the La Plata (Pez Limón) bank. Thalassas, 25, 21-26.

Isla, F. I., \& Toldo, E. E. (2013). ENSO impacts on Atlantic watersheds of South America. Quaternary and Environmental Geosciences, $4,34-41$.

Isla, F. I., Rutter, N. W., Schnack, E. J., \& Zárate, M. A. (2000). La transgresión Belgranense en Buenos Aires. Una revisión a cien años de su definición. Revista Cuaternario y Ciencias Ambientales, Asociación Geológica Argentina, 1, 3-14.

Kanner, L. C., Burns, S. J., Cheng, H., Edwards, R. L., \& Vuille, M. (2013). High-resolution variability of the South American summer monsoon over the last seven millennia: Insights from a speleothem record from the central Peruvian Andes. Quaternary Science Reviews, 75, 1-10.

Luengo, M. S., Ballesteros-Prada, A., Vilanova, I., Bernasconi, E., \& Fucks, E. (2021). Environmental changes related to the Holocene sea-level transgression and successive highstand (7-5.5 Kyr) at the NE coastal plain of Buenos Aires. Argentina. Quaternary International. https://doi.org/10.1016/j.quaint2021.03.006

Mackey, R. (2007). Rhodes Fairbridge and the idea that the solar system regulates the Earth's climate. Journal of Coastal Research, 50, 955-968.

Marcomini, S., Tripaldi, A., Leal, P., López, R., Alonso, M. S., Ciccioli, P. L., Quesada, A., \& Bunicontro, P. (2018). Morfodinámica y sedimentación de un sector del frente deltaico del Paraná entre los años 1933 y 2016, provincia de Buenos Aires, Argentina. Revista De La Asociación Geológica Argentina, 75, 1-16.

Markgraf, V., \& Diaz, H. F. (2000). The past ENSO record: A synthesis. In H. F. Diaz \& V. Markgraf (Eds.), El Niño and the Southern oscillation: Multiscale variability and global and regional impacts (pp. 465-488). Cambridge University Press.

Martinez, S., \& Rojas, A. (2013). Relative sea level during the Holocene in Uruguay. Palaeogeography, Palaeoclimatology, Palaeoecology, 374, 123-131.

Martinez, S., Del Rio, C. J., \& Rojas, A. (2016). A Pleistocene (MIS 5e) mollusk assemblage from Ezeiza (Buenos Aires Province, Argentina). Journal of South American Earth Sciences, 70, 174-187.

Martínez, S., Ubilla, M., Verde, M., Perea, D., Rojas, A., Guérequiz, R., \& Piñeiro, G. (2001). Paleoecology and geochronology of Uruguayan coastal marine Pleistocene deposits. Quaternary Research, 55, 246-254. https://doi.org/10.1006/qres.2000.2204

Mauas, P. J. D., Buccino, A. P., \& Flamenco, F. (2011). Long-term solar activity influences in South American rivers. Journal of Atmospheric and Solar-Terrestrial Physics, 73, 377-382.

Mauz, B., \& Hassler, U. (2000). Luminiscence chronology of Late Pleistocene raised beaches in southern Italy: New data of relative sea-level changes. Marine Geology, 170, 187-203.

McCormac, F. G., Hogg, A. G., Blackwell, P. G., Buck, C. E., Higham, T. F. G., \& Reimer, P. J. (2004). SHCal04 Southern Hemisphere calibration, 0-11.0 cal KyBP. Radiocarbon, 46, 1087-1092.

Milana, J. P., \& Kröhling, D. (2015). Climate change and solar cycles recorded at the Holocene Paraná Delta and their impact on human population. Scientific Reports, 5, 12.851. https://doi.org/10.1038/ srep12851

Orfeo, O. (1995). Sedimentología del Río Paraná en el área de su confluencia con el Río Paraguay. PhD. p. 250. Universidad Nacional de la Plata.

Otvos, E. G. (2000). Beach ridges: Definitions and significance. Geomorphology, 32, 83-108.

Otvos, E. G., \& Price, W. A. (1979). Problems of Chenier genesis and terminology-an overview. Marine Geology, 31, 251-263.

Parker, G., Violante, R. A., Paterlini, G. M., Costa, I. P., Marcolini, S. I., \& Cavallotto, J. L. (2008). Las secuencias depositacionales del Plioceno-Cuaternario en la plataforma submarina adyacente al litoral del este bonaerense. Latin American Journal of Sedimentology and Basin Analysis, 15, 105-124.

Pasquini, A., \& Depetris, P. (2010). ENSO-triggered exceptional flooding in the Parana River: Where is the excess water coming from? Journal of Hydrology, 383, 186-193.

Phillippsen, B. (2013). The freshwater reservoir effect in radiocarbon dating. Heritage Science. https://doi.org/10.1186/2050-7445-1-24

Prieto, A. R., Mourelle, D., Peltier, W. R., Drummond, C., Vilanova, I., \& Ricci, L. (2017). Relative sea-level changes during the Holocene in the Río de la Plata, Argentina, and Uruguay: A review. Quaternary International, 442, 35-49.

Quesada, A. (2019). Geomorfología ambiental de la Primera Sección del delta del río Paraná: evolución de los canales distributarios, erosión antropogénica y manejo de márgenes. PhD Thesis, University of Buenos Aires, Buenos Aires, p. 229.

Rapela, C. W., Pankhurst, R. J., Casquet, C., Fanning, C. M., Baldo, E. G., González-Casado, J. M., Galindo, C., \& Dahlquist, J. (2007). The Río de la Plata craton and the assembly of SW Gondwana. Earth-Science Reviews, 83(1-2), 49-82. https://doi.org/10.1016/j. earscirev.2007.03.004

Robinson, R. A. J., Spencer, J. Q. G., Strecker, M. R., Richter, A., \& Alonso, R. N. (2005). Luminiscence dating of alluvial fans in intramontane basins of NW Argentina. Geological Society London, Special Publication, 251, 153-168. 
Rodríguez, A. B., Hamilton, M. D., \& Anderson, J. B. (2000). Facies and evolution of the modern Brazos Delta, Texas: Wave versus flood influence. Journal of Sedimentary Research, 70, 283-295.

Rosello, E. A., Veroslavsky, G., Santa Ana, H., \& Rodríguez, P. (2018). Geology of the Río de la Plata and the surrounding areas of Argentina and Uruguay related to the evolution of the Atlantic margin. Journal of South American Earth Sciences, 83, 147-164.

Sánchez-Bettucci, L., Koukharsky, M., Pazos, P., \& Stareczek, S. (2009). Neoproterozoic subaqueous extrusive-intrusive rocks in the Playa Hermosa Formation in Uruguay: Regional and stratigraphic significance. Gondwana Research, 16, 134-144.

Sarubbi, A., Pittau, M., \& Menéndez, A. N. (2004). Delta del Paraná: Balance de sedimentos. Instituto Nacional del Agua. Informe LHA 02-235-04. Retrieved December 15, 2017, from https://studylib. es/doc/7428340/delta-del-paraná--balance-de-sedimentos.

Schuerch, M., Scholten, J., Carretero, S., García-Rodríguez, F., Kumbier, K., Baechtinger, M., \& Liebetrau, V. (2016). The effect of long-term and decadal climate and hydrology variations on estuarine marsh dynamics: An identifying case study from the Río de la Plata. Geomorphology, 269, 122-132.

Stuiver, M., \& Braziunas, T. F. (1993). Modelling atmospheric ${ }^{14} \mathrm{C}$ influences and ${ }^{14} \mathrm{C}$ ages of marine samples to 10,000 BC. Radiocarbon, 35, 137-189.
Tanner, W. F. (1995). Origin of beach ridges and swales. Marine Geology, 129, 149-161.

Tedeschi, R. G., \& Collins, M. (2016). The influence of ENSO in South American precipitation during austral summer and autumn in observations and models. International Journal of Climatology, $36,618-635$.

Teruggi, M. (1957). The nature and origin of the Argentine loess. Journal of Sedimentary Research, 27, 322-332.

Ulm, S. (2000). Marine and estuarine reservoir effects in central Queensland, Australia: Determination of $\Delta \mathrm{R}$ values. Geoarchaeology, 17, 319-348.

Urien, C. M. (1972). Rio de la Plata Estuary Environments. Geological Society of America Memoirs, 133, 213-234.

Vanoni, V. A. (1975). Sedimentation Engineering. American Society of Civil Engineers, Manual, 54, 1-424.

Whang, R., \& Ren, H. L. (2017). The linkage between two ENSO types/modes and the interdecadal changes of ENSO around the year 2000. Atmospheric and Oceanic Science Letters, 10, $168-174$. 